\title{
Interannual variability of ozone and carbon monoxide at the Whistler high elevation site: 2002-2006
}

\author{
A. M. Macdonald, K. G. Anlauf, W. R. Leaitch, E. Chan, and D. W. Tarasick \\ Science and Technology Branch, Environment Canada, 4905 Dufferin Street, Toronto, Ontario, Canada \\ Received: 11 May 2011 - Published in Atmos. Chem. Phys. Discuss.: 22 June 2011 \\ Revised: 18 October 2011 - Accepted: 27 October 2011 - Published: 17 November 2011
}

\begin{abstract}
In spring 2002, an atmospheric measurement site was established at the peak of Whistler Mountain in British Columbia, Canada to measure trace gases, particle chemistry and physics, and meteorology. This paper uses continuous measurements from March 2002 to December 2006 to investigate the influence of trans-Pacific transport and North American forest fires on both $\mathrm{O}_{3}$ and $\mathrm{CO}$ at Whistler. Annual mean mixing ratios of $\mathrm{O}_{3}$ and $\mathrm{CO}$ were 41 ppbv (monthly means of 35-48 ppbv) and $145 \mathrm{ppbv}$ (monthly means of 113-177 ppbv) respectively with both species exhibiting an annual cycle of late-winter to early-spring maxima and summer minima. The absence of a broad summer $\mathrm{O}_{3}$ peak differs from previously-reported high altitude sites in the western US. The highest monthly-averaged $\mathrm{O}_{3}$ and $\mathrm{CO}$ mixing ratios relative to the 5-yr monthly means were seen in fall 2002 and spring 2003 with increased $\mathrm{O}_{3}$ and $\mathrm{CO}$ of $10 \%$ and $25 \%$ respectively. These increases correspond to anomalouslyhigh values reported at other Northern Hemisphere sites and are attributed to fires in the Russian Federation. Air mass back trajectory analysis is used to associate the mean enhancements of $\mathrm{O}_{3}$ and $\mathrm{CO}$ with trans-Pacific transported or North American air masses relative to the Pacific background. Mean values of the enhancements for March to June in trans-Pacific air masses were $6 \mathrm{ppbv}$ and $16 \mathrm{ppbv}$ for $\mathrm{O}_{3}$ and $\mathrm{CO}$ respectively. In summers 2002-2006, higher CO and $\mathrm{O}_{3}$ mixing ratios were almost always observed in North American air masses and this relative enhancement co-varied for each year with the western US and Canada total wildfire area. The greatest enhancements in $\mathrm{O}_{3}$ and $\mathrm{CO}$ were seen in 2004, a record year for forest fires in Alaska and the Yukon Territory with average $\mathrm{O}_{3}$ and $\mathrm{CO}$ mixing ratios 13 and 43 ppbv above background values.
\end{abstract}

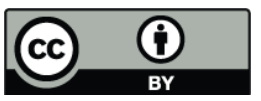

Correspondence to: A. M. Macdonald (annemarie.macdonald@ec.gc.ca)

\section{Introduction}

Factors affecting lower tropospheric ozone are important for the development of policies for local and regional pollution control as well as for evaluating the effectiveness of these controls. Ozone is both a constituent of smog and a greenhouse gas, and it plays a role in controlling the oxidizing capacity of the troposphere. Tropospheric ozone $\left(\mathrm{O}_{3}\right)$ is formed primarily by the oxidation of carbon monoxide (CO) and non-methane hydrocarbons (NMHCs) in the presence of nitrogen oxides $\left(\mathrm{NO}_{\mathrm{x}}\right)$. Emissions of ozone precursors are from both anthropogenic and biogenic sources. NMHCs are emitted from vegetation, fossil fuel combustion, and manufacturing; major sources of $\mathrm{NO}_{\mathrm{x}}$ include fossil fuel burning, lightning, emissions from the biosphere, and stratospheric injections. Biomass burning is also a significant source of $\mathrm{CO}$, NMHCs and $\mathrm{NO}_{\mathrm{x}}$ (Crutzen and Andreae 1990; Galanter et al., 2000; Simpson et al., 2011) and during the boreal fire season has been shown to influence regional ozone in North America (Wotawa and Trainer, 2000; McKeen et al., 2002).

On the west coast of North America, the contribution to regional ozone of trans-Pacific transported ozone and its precursors also needs to be considered. Over the past two decades, observational and modelling studies have shown that particle and trace gas concentrations throughout the Northern Hemisphere are influenced by intercontinental and hemispheric transport. Trans-Pacific transport of pollutants was first recognized as an issue in the late 1980s and early 1990s (Andreae et al., 1988; Kritz et al., 1990). Since then, numerous studies have documented pollution reaching the west coast of North America resulting in increases in ground level particles, $\mathrm{O}_{3}, \mathrm{CO}$, and pesticides (e.g. Husar et al., 2001; Jaffe et al., 2003; Bailey et al., 2000; Singh et al., 2009 and references therein). Jaffe et al. (1999) showed that transport of pollutants across the Pacific could have an impact on ground-level ozone in the Western US. Modelling studies have furthered the understanding of how transport may affect

Published by Copernicus Publications on behalf of the European Geosciences Union. 
overall air quality and chemistry on the west coast of North America. Pollution crossing the Pacific Ocean was estimated to increase CO over western US by up to $25 \%$ (Liang et al, 2004; Stohl et al., 2002). Anticipated three-fold increases in Asian industrial emissions from 1985-2010 were calculated to result in a 2-6 ppbv increase in ground-level ozone in the western US (Jacob et al., 1999).

To understand the factors affecting $\mathrm{O}_{3}$ budgets, comparisons of $\mathrm{O}_{3}$ with $\mathrm{CO}$ have been made in North American outflow and also at sites on the west coast of the US (Parrish et al., 1998; Weiss-Penzias et al., 2004; Honrath et al., 2004; Val Martin et al., 2006). The basis for the $\mathrm{CO}$ and $\mathrm{O}_{3}$ comparison is the assumption that $\mathrm{CO}$ mixing ratios are directly related to $\mathrm{CO}$ and $\mathrm{O}_{3}$ precursor emissions such as nonmethane hydrocarbons and nitrogen oxides, and that changes in $\mathrm{CO}$ are indicative of changes in $\mathrm{O}_{3}$ precursor species and thus would exhibit a relationship with net ozone production (Parrish et al., 1993, 1998; Honrath et al., 2004). Annual and interannual variability in $\mathrm{CO}$ is strongly dependent on both fossil fuel emissions and biomass burning (Novelli et al., 2003; Wotawa et al., 2001; Yurganov et al., 2005).

Trends in background ozone have been identified for several sites in western North America. Jaffe and Ray (2007) have examined 20 years of data (1987-2004) and found an average increase of $0.26 \mathrm{ppbv} / \mathrm{year}$ of $\mathrm{O}_{3}$. Parrish et al. (2009) have found a similar trend from looking at west coast marine boundary layer sites ( $0.34 \mathrm{ppbv} / \mathrm{year})$. Chan and Vet (2010) used a muti-site cluster analysis and also found a significant upward trend in background ozone along the west coast of North America. Similar trends have been identified in free tropospheric measurements through a comprehensive integration of data from multiple years and west coast studies (Cooper et al., 2010). Reasons for these trends are unclear and several possibilities have been suggested including regional continental or ship emissions, biomass burning and trans-Pacific transport (Cooper et al., 2010; Jaffe and Ray 2007; Dalsoren et al., 2010; Jaffe, 2010).

Relationships between $\mathrm{O}_{3}$ and $\mathrm{CO}$ in North America over multiple years have mostly been made at ground-level sites (e.g. Parrish et al., 1998). Although transport of pollutants is observed at ground-level sites, significant transport occurs in the free troposphere and therefore, the frequency of observable transport events should increase at a high elevation site (VanCuren and Cahill, 2002). In addition, measurements in the free troposphere, largely unaffected by local emissions, are valuable to understand the regional and long-range emission and transport influences. Most coupled $\mathrm{CO}$ and $\mathrm{O}_{3}$ data from the free troposphere come from aircraft campaigns which often include a detailed suite of measurements with good spatial coverage but are of limited time duration. Major field campaigns over the Pacific since the early 1980s have provided coupled $\mathrm{CO}$ and $\mathrm{O}_{3}$ measurements (e.g. Talbot et al., 1994; Heald et al., 2003; Bertschi et al., 2005; Liang et al., 2007). Satellite observations also expand the spatial and temporal scale of both emission and transport of pollutants. In particular, the integration of satellite, aircraft, and ground-based measurements furthers the understanding of processes related to transportation and transformation of pollutants (e.g. Zhang et al., 2008).

High elevation surface sites in western North America can provide long-term measurements in the lower free troposphere. Long-term records of ozone are available from several US National Park sites with varying degrees of influence from regional pollution (Jaffe and Ray, 2007). The Mt Bachelor site in central Oregon (Weiss-Penzias et al., 2004) is well situated for background free-tropospheric chemistry and atmospheric measurements began there in spring 2004.

In March 2002, Environment Canada began measurements of particles and some trace gases at the peak of Whistler Mountain, Whistler, British Columbia (hereafter called Whistler Peak). Situated about $100 \mathrm{~km}$ from the west coast of Canada, the Whistler Peak site was established to provide a baseline of particles and trace gases in the lower free-troposphere, and to examine incidences of trans-Pacific transport of dust and pollution into western Canada. This paper presents $\mathrm{O}_{3}$ and $\mathrm{CO}$ measurements from 2002-2006, including their annual and interannual variability. Enhancement of $\mathrm{CO}$ and $\mathrm{O}_{3}$ for trans-Pacific air masses is identified for springtime versus summer and compared to the relative enhancement in North American air masses above the Pacific background. The summer enhancements observed in $\mathrm{O}_{3}$ and $\mathrm{CO}$ are then related to the interannual variability of forest fires.

\section{Experimental}

\subsection{Site details}

Whistler Mountain, approximately $100 \mathrm{~km}$ north of Vancouver, is part of the Coast Mountain range, a subset of the Pacific Cordillera extending along the west coast of North America from Alaska to Southern California. This high elevation site $\left(50.06^{\circ} \mathrm{N}, 122.96^{\circ} \mathrm{W}, 2182 \mathrm{~m}\right.$ a.s.l. $)$ was chosen because of its relatively high exposure to the background troposphere, low impact expected from local pollution, and year-round accessibility. It is located just above the Whistler glacier, approximately $400 \mathrm{~m}$ above the tree line. The mountain peak is usually snow covered except for July to September. Whistler village lies just north of the site at about $650 \mathrm{~m}$ a.s.l. elevation. Vegetation in the surrounding valleys is mixed forest, dominated by coniferous trees.

Samplers are located in the chair lift operator's hut. Access is provided through Whistler-Blackcomb mountain operations. The site operates year round although for about one month during each of the late spring and fall, operatorrequired sampling is suspended because of limited site access. Pollution influences from trucks, snowmobiles or snow grooming equipment are readily identified and have been removed from the dataset. 
Trace gases are sampled through a $1 / 4^{\prime \prime}$ Teflon sample line, with a $5 \mu \mathrm{m}$ in-line Teflon filter to remove particles and mounted approximately $5 \mathrm{~m}$ above the ground. All site measurements were recorded, and are reported here, as Pacific Standard Time (PST).

\subsection{Trace gases ozone and $\mathrm{CO}$}

Carbon monoxide was measured continuously with a Thermo Environmental Instruments Inc. Model 48C-Trace Level analyzer which determines $\mathrm{CO}$ by non-dispersive Infrared Spectrophotometry (NDIR). Calibrations were carried out approximately 3-4 times per year with a NIST traceable standard and were stable throughout the four year period, changing by less than $3 \%$. The accuracy of the calibration points, taken as three standard deviations of the $100 \mathrm{ppbv}$ standard point was within $10 \mathrm{ppbv}$. The detection level was about 19 ppbv determined as three times the standard deviation of the instrument zero. Instrument zeros were done every two hours for the period of March 2002-2005, every halfhour for March 2005-2006, and hourly after March 2006. The instrument background was taken as a linear interpolation with time between consecutive zeros and this approach was valid when the operating temperature changed monotonically with time. Changes of $1{ }^{\circ} \mathrm{C}$ of operating temperature could result in a 25 ppbv difference in CO. Installation of a thermostatically controlled fan usually maintained the room temperature to $\pm 0.5^{\circ} \mathrm{C}$. For cases in which the temperature fluctuated within the two-hour period, the background was calculated as a function of temperature. The standard error on this temperature versus background voltage over a multiple-hour period was $15-20$ ppbv.

Ozone was measured with a Thermo Environmental Instruments Inc. UV absorption monitor (TECO 49C). Ozone zeros were carried out every 48 hours with an in-line Koby air purifier cartridge. The instrument was calibrated every 3-4 months with a NIST traceable Dasibi Model 1008 PC ozone calibrator. Over the period March 2002 to March 2006, the calibration factors varied by less than $1 \%$; the detection level was about $0.5 \mathrm{ppbv}$ and the uncertainty of the measured ozone concentrations was within $\pm 0.5 \mathrm{ppbv}$.

\subsection{Meteorological measurements}

Meteorological measurements at the site include temperature, pressure and relative humidity. Pressure is measured with a Vaisala PTB101B pressure sensor. Temperature and relative humidity are both measured with a Campbell Scientific HMP45CF probe. Additional meteorological measurements (wind speed and direction) are made available through Whistler-Blackcomb on an hourly time resolution.

Fog is detected with an optical cloud detector (MCD-05, Associated Weather Services, Inc).

Ten-day back trajectories with the arrival pressure specified at $750 \mathrm{hPa}$ (the approximate mean pressure at the site) were used, calculated with the trajectory model of the Canadian Meteorological Centre (D'Amours and Page, 2001). The model uses 3-D analyzed wind fields and trajectories are calculated on an $\mathrm{X}$ by $\mathrm{Y}$ grid. Trajectories were calculated for arrival time at Whistler every six hours.

\section{Results and discussion}

\subsection{Meteorology}

Monthly average temperatures from all hours of data at Whistler Peak (March 2002 to December 2006) range from $-8.3^{\circ} \mathrm{C}$ in winter to $9.4^{\circ} \mathrm{C}$ in summer. Maximum temperatures are commonly in July and August, although during 2003 the maximum temperature was in June followed by lower-than-average temperatures during the autumn. The predominant wind direction is westerly to southwesterly with gusts reaching $150 \mathrm{~km} \mathrm{~h}^{-1}$ during winter storms.

Clouds also impact this high elevation site. Although the fog detector gives no information on cloud amount, it provides qualitative information on cloud frequency. Data are available for an entire year (April 2002-June 2003) and three fall-through-spring periods (September 2003-March 2004; October 2004-May 2005; September 2005-April 2006). The percent of time during each available period that the site was in cloud at each hour of the day ranged from $8-20 \%$ for entirely cloud covered to $15-40 \%$ for greater than $10 \mathrm{~min}$ out of an hour. Cloud coverage increased from morning to afternoon with a decrease again at approximately 1600 (PST).

Several approaches have been used to separate boundary layer from free troposphere influenced data. Weiss-Penzias et al. (2006) compared water vapour at the Mt. Bachelor site with that from nearby radiosondes. Kleissl et al. (2006, 2007) provided a detailed examination of the effects of buoyant upslope flow or mechanical lifting on the Azores Pico site through the use of observed vertical soundings supplemented by those from a European numerical weather model. A simplified approach is used here to estimate the timing of the boundary layer influence on the mountain peak $\mathrm{CO}$ and $\mathrm{O}_{3}$ mixing ratios. In spring 2005 (May) and 2006 (March-June) Whistler Peak temperature data were supplemented by temperature data from the Environment Canada National Archives Climate Database, and additional temperature records from two temporary sensors (MadgeTech, Temp101) to provide temperature measurements at $300 \mathrm{~m}$ vertical intervals up the mountain. The calculated temperature lapse rates from $1000 \mathrm{~m}$ to $2182 \mathrm{~m}$ were compared to the dry and wet adiabatic lapse rates to determine if the air mass was unstable, conditionally unstable, or stable with the assumption that the air mass was mixed under unstable conditions. A value of 1-3 was assigned to each hour based on the stability calculations ( $1=$ unstable; $2=$ conditionally unstable; $3=$ stable), to estimate of the timing of the transition from stable to unstable conditions. Figure 1 shows 


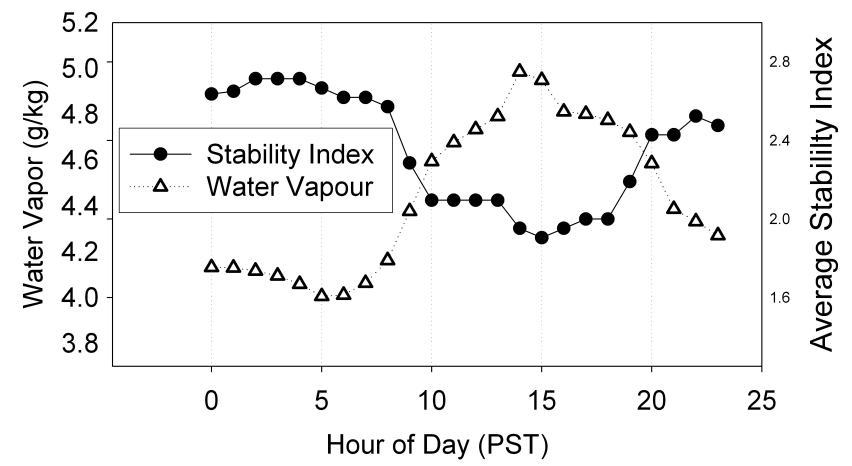

Fig. 1. Diurnal variation in water vapour and stability at Whistler Peak for May 2006. The stability Index of 3 describes stable conditions and 1 is unstable or assumed mixed conditions.

the diurnal variation in this "stability index" and in water vapour for the month of May 2006. The calculations confirmed mixing to the site from lower levels during springtime with the transition from stable to conditionally unstable conditions at approximately 08:00-09:00 PST and return to stable conditions by 17:00-20:00 PST. Although this simple technique only addresses one possible reason for boundary layer influence, it provides some time of day estimates for data segregation, agrees well with a more detailed meteorological analysis over an entire year (Gallagher et al., 2011), and supports the time of day approach employed by Andrews et al. (2011) for several mountain-top sites. Very little valley influence is expected in winter as the snow covered surface suppresses convective lifting of the boundary layer to the Peak level. Daytime growth of the boundary layer to encompass the mountain site was also confirmed from aircraft profiles of particles and gases during the INTEX-B campaign of spring 2006 (Leaitch et al., 2009). Early morning profiles showed a decoupling of the boundary layer and free troposphere below the peak while the afternoon profiles most often showed a mixed boundary layer up to $3 \mathrm{~km}$.

\subsection{Trace gases}

\subsubsection{Influence of boundary layer or free troposphere}

The extent of the boundary layer influence is considered next by examination of the diurnal cycles in $\mathrm{O}_{3}, \mathrm{CO}$, and water vapour as a function of season (Fig. 2). (Note that although the absolute values differ among the seasons, the ranges are consistent in all four panels). In winter (Fig. 2a) there is little diurnal variation with $\mathrm{O}_{3}$ changing by less than $0.5 \mathrm{ppbv}$. Water vapour begins to increase at approximately 10:00 PST and $\mathrm{CO}$ changes by less than 1 ppbv throughout the daytime. Overnight, CO mixing ratios average $1-3$ ppbv higher than daytime values. The reason for this increase is unclear and may be an indication of transport layers. The possibility of increased influence from grooming equipment overnight in winter may be considered but would not explain the repeated pattern in fall. As the valley warms, during the late spring months and early summer (MJJA), the mountain site becomes more influenced by valley air mixed up to the site. In summer (Fig. 2b), a decrease in averaged ozone is observed at approximately 08:00-09:00 PST as the nocturnal inversion in the valley breaks up and air with lower ozone reaches the site. This decrease in ozone is coincident with increases in water vapour and $\mathrm{CO}$, both indicative of the boundary layer influence. At lower elevations in the nocturnal boundary layer, ozone may be lost through titration with $\mathrm{NO}$ or also through deposition processes. When mixing begins in the morning, the Peak first sees the effects of nighttime ozone loss but then by mid-day ozone begins to rise as mixing continues and ozone may be mixed down from higher elevations to the Peak. By late afternoon, ozone often exceeds its nighttime value, peaking at approximately 17:00-18:00 PST. This late afternoon rise to values on average $1 \mathrm{ppbv}$ higher than nighttime may be due to photochemically-produced ozone and is coincident with a secondary CO peak. $\mathrm{CO}$ is not only a good tracer for pollution and biomass burning, it also increases as a result of the oxidation of biogenic NMHCs (e.g. Hudman et al., 2008; Slowik et al., 2010) which may contribute to this secondary peak. In summer, the average maximum diurnal changes in $\mathrm{CO}$ and $\mathrm{O}_{3}$ during JJA are $6 \mathrm{ppbv}$ and 3.5 ppbv respectively (Fig. 2b). The spring (Fig. 2c) and fall (Fig. 2d) months show similar patterns with the ozone decrease happening later in the morning and with the overall diurnal change reduced; photochemical production is lower than during summer. The largest diurnal variation in ozone was during July 2004 at approximately $10 \%$ change about a daily mean value.

To minimize the impact of the boundary layer chemistry on calculating averages for the free troposphere, the monthly mixing ratios are calculated from nighttime data only (20:0008:00 PST). It is noted, however, that $81 \%$ of the averages showed differences of less than $1 \%$ between all hours and nighttime only; the largest difference in monthly averages calculated with all data and nighttime only data was $2.2 \%$ for $\mathrm{O}_{3}$ (June 2005) and $1.6 \%$ for CO during (August 2002, August 2004).

\subsubsection{Ozone}

Ozone for March 2002 to December 2006 at Whistler Peak is given in Fig. 3a as monthly averages of nighttime data with the 5-yr average annual cycle superimposed. As also shown in Fig. 4a, the ozone mixing ratios mostly range from 20-60 ppbv (90\% of data are between 28 and $53 \mathrm{ppbv}$ ) with greater variability in spring and summer values. Monthlyaveraged ozone varied from a high of about $45-50 \mathrm{ppbv}$ in springtime to a low of $32-40 \mathrm{ppbv}$ in summer. Annual median mixing ratios ranged from 40 to $43 \mathrm{ppbv}$ over the years 2002 to 2006 (Table 2). These are 15-20 ppbv higher than the annual medians (23-27 ppbv) reported at a regional coastal 

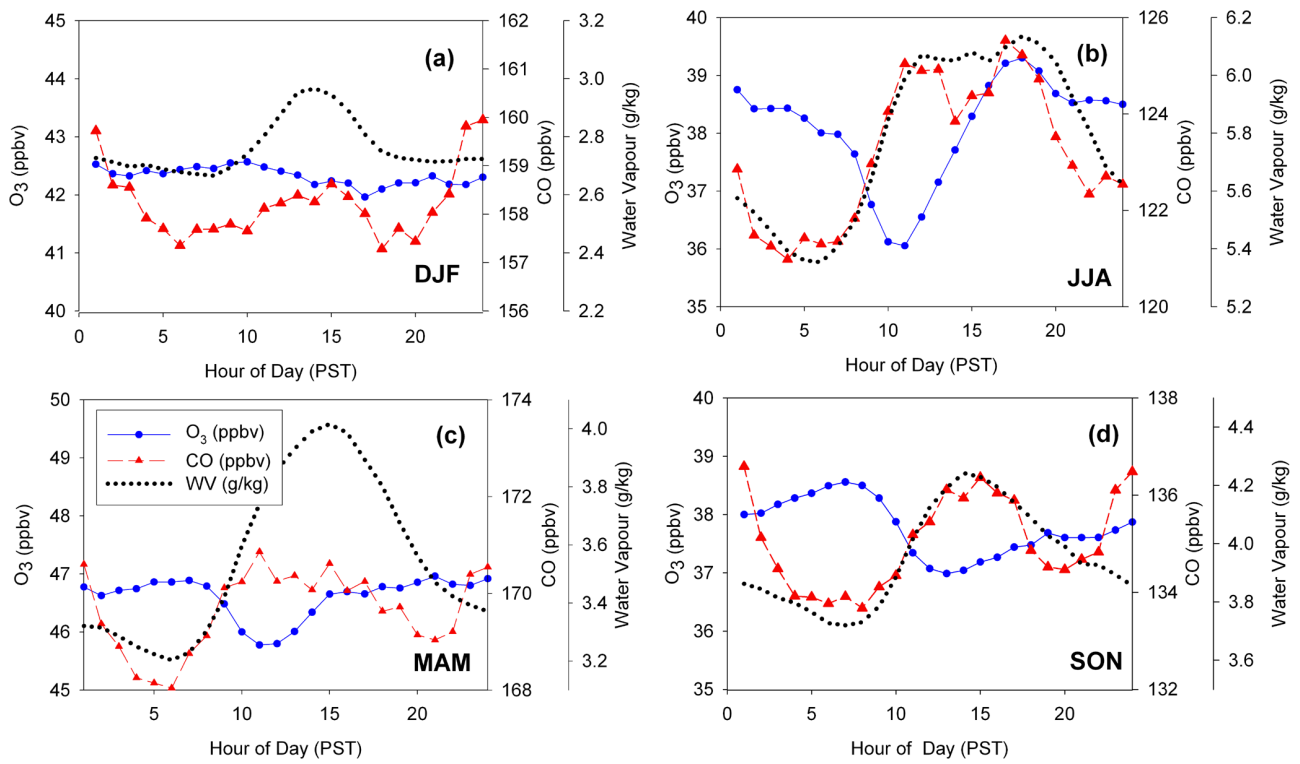

Fig. 2. Diurnal variation in ozone, CO, and water vapour at Whistler Peak 2002-2006 for (a) December-February, (b) June-August, (c) March-May, and (d) September-November. CO mixing ratios are averages of data smoothed with a three-hour running mean.

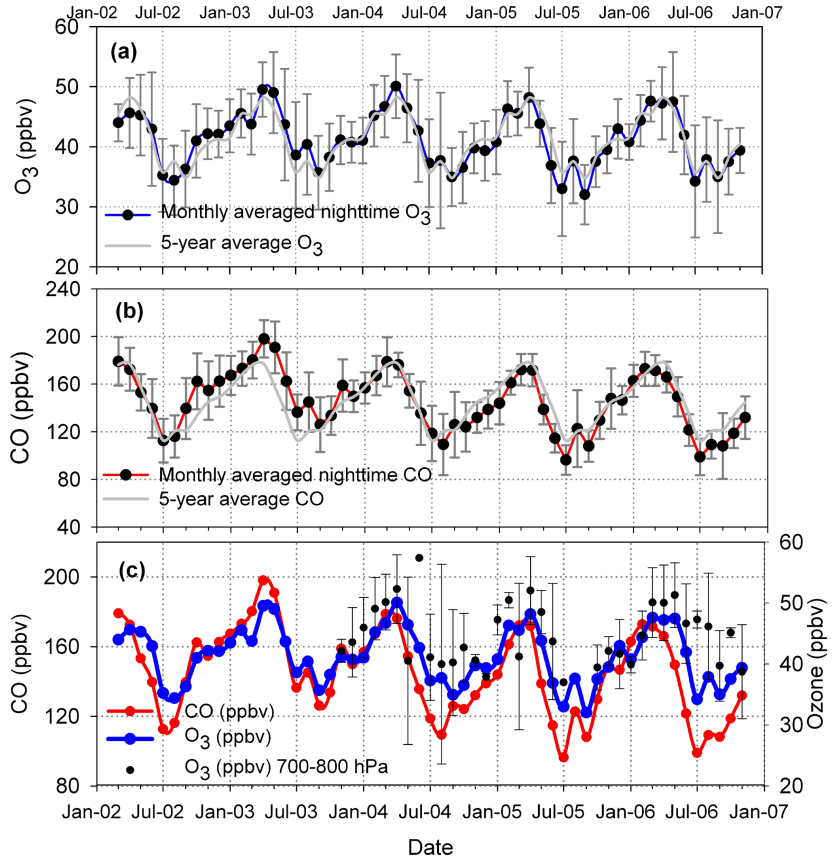

Fig. 3. Monthly averages of (a) $\mathrm{O}_{3}$ and (b) $\mathrm{CO}$ nighttime data (20:00-08:00 PST) for March 2002 to December 2006 at Whistler Peak. Error bars are one standard deviation about the mean of all hourly data. The gray lines show the 5-yr averages. (c) Monthly averages of both $\mathrm{O}_{3}$ and $\mathrm{CO}$ from Whistler peak and $\mathrm{O}_{3}$ mixing ratios from ozonesondes flown at Kelowna, British Columbia. The error bars are one standard deviation of the reported values of $\mathrm{O}_{3}$ from $700-800 \mathrm{hPa}$.
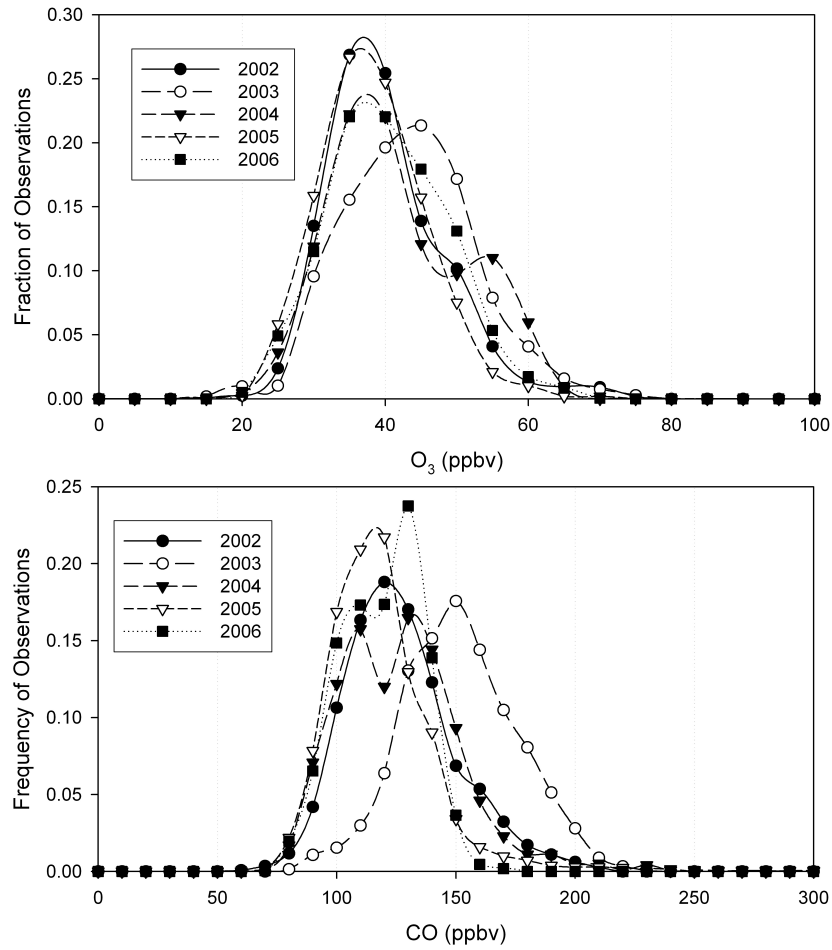

Fig. 4. (a) Frequency distributions of $\mathrm{O}_{3}$ mixing ratios for June-August 2002-2006; (b) Frequency distribution of CO mixing ratios for June-August 2002-2006. 
site in British Columbia for 1992-2001 (Saturna Island) but consistent with high elevation sites in the Western United States; annual medians at Lassen National Park, California (1995-2001) were 38-43 ppbv (Vingarzen, 2004). This range of values is also consistent with annual baseline values determined for the Canadian coastal sites (19 ppbv) and US coastal sites (39 ppbv), by Chan and Vet (2010) who acknowledged that site elevation was a major difference between the two groups.

The amplitude of the annual signal (approximately $14 \mathrm{ppbv}$ ) is 5 ppbv less than that reported for Cheeka Peak (Weiss-Penzias et al., 2004) or Trinidad Head (TDH), California (Oltmans et al., 2008) which are both lower-altitude marine boundary layer sites. The observed ozone cycle at Whistler differs from other high elevation sites in the western US such as Rocky Mountain and Lassen National Parks (Jaffe and Ray, 2007; Jaffe, 2011) or from ozonesondes flown at TDH (Parrish et al., 2010). These sites have the spring ozone peak but also have a significant summer peak, sometimes exceeding the springtime maxima. The Whistler ozone data do not show this broad summer maximum and more closely resemble the annual ozone pattern from the coastal TDH site (Oltmans et al., 2008) although monthly median mixing ratios are 3-15 ppbv higher at Whistler $\left(\mathrm{O}_{3}\right.$ $\left.\mathrm{WHI}=0.7\left(\mathrm{O}_{3} \mathrm{TDH}\right)+19.8 \mathrm{ppbv} ; R^{2}=0.74, n=56\right)$. The small secondary peak often observed in August at Whistler was not observed at TDH, and corresponded with increases in Whistler CO, possibly indicative of regional pollution or influences of biomass burning. Seasonal ozone mixing ratios from Mt Bachelor for 2004-2009 reach a maximum in springtime at $50 \mathrm{ppbv}$ for free-troposphere (FT) air masses and $44 \mathrm{ppbv}$ non free troposphere (non-FT) (Ambrose et al., 2011). In fall through spring, the Whistler seasonal averages fall mid-way between the FT and non-FT values reported at Mt Bachelor but in summer, ozone at Whistler agrees most closely with the non-FT value of $39 \mathrm{ppbv}$.

It is possible that the broad spring-summer maximum is not observed at Whistler because it is influenced more by the boundary layer in summer than are other elevated sites in the Western US. This was explored by comparing ozone mixing ratios from ozonesondes flown from Kelowna, $\mathrm{BC},\left(49.94^{\circ} \mathrm{N}, 119.4^{\circ} \mathrm{W}\right)$, a site approximately $300 \mathrm{~km}$ east of Whistler (Tarasick and Slater., 2008). Figure 3c shows monthly averaged ozone mixing ratios measured from ozonesondes for the altitude range $700-800 \mathrm{hPa}$ from November 2003-December 2006. With the exception of April, May and August 2006, data are available from 1-4 sondes per month. Mixing ratios agree well between the two sites and the sonde data also show a decrease in ozone from spring into summer but this decrease is less than that observed at Whistler. The variability in data from these weekly sondes is high but in August 2006, daily sondes were flown late afternoon and the mean $\mathrm{O}_{3}$ for $700-800 \mathrm{hPa}$ is $8 \mathrm{ppbv}$ higher than at Whistler. Future investigation of vertical profiles through the ozonesonde intensive sampling periods will provide additional insight into the spring-summer differences in ozone mixing ratios.

The highest positive anomalies in ozone in relation to 5-yr monthly means (Fig 3a) were in fall 2002 through spring and summer 2003 with ozone up to $10 \%$ higher than the 5-yr average. Frequency distributions of $\mathrm{O}_{3}$ over the summer (JJA) period (Fig. 4a) illustrate the shift in $\mathrm{O}_{3}$ to higher values throughout summer 2003; the mode has shifted from $36 \mathrm{ppbv}$ to about 45 ppbv. The summer 2004 distribution is bimodal with a high mode at 55-60 ppbv and low mode $\sim 35-40 \mathrm{ppbv}$, corresponding to the location of the single modes for 2002, 2005, 2006. This higher shoulder mode in 2004 is related to air masses influenced by biomass burning and is also reflected in the distributions of $\mathrm{CO}$ (Fig. 4b).

\subsubsection{Carbon monoxide}

Monthly averages of nighttime-only carbon monoxide are shown in Fig. 3b. On average, CO ranged from 100 to $200 \mathrm{ppbv}$, exhibiting a strong seasonal cycle with the maximum value in springtime and minimum in summer. There is a higher degree of variability in summer than winter (the standard deviation for winter data is $14-19$ ppbv and for JunAug is 16-27 ppbv) resulting from increased regional emission sources during summer and an increase of boundary layer influence. This annual cycle is consistent with other remote sites on the west coast of North America (eg. Cheeka Peak; Weiss-Penzias et al., 2004). CO mixing ratios at Whistler are remarkably similar to those reported for Mt. Bachelor for the period spring 2004 to summer 2005 (Reidmiller et al., 2008) although the values at Mt. Bachelor are 15-20 ppbv lower than the Whistler values for October 2006-July 2007.

The seasonal cycle in $\mathrm{CO}$ has been well documented (Novelli et al., 1998; Novelli et al., 2003) and is attributed to a combination of photochemistry and transport. It is characterized by a slow increase in $\mathrm{CO}$ throughout the fall and winter followed by a rapid decline in springtime as $\mathrm{OH}$ concentrations increase (Novelli et al., 1998). The main sources of CO in the Northern Hemisphere are combustion of fossil fuels, biomass burning, oxidation of methane and oxidation of nonmethane hydrocarbons (NMHCs) whereas the main sinks of $\mathrm{CO}$ are oxidation with $\mathrm{OH}$ and transport of $\mathrm{CO}$ to the Southern Hemisphere (Novelli et al., 1998; Holloway et al., 2000).

Novelli et al. (1998) show that in the absence of biomass burning, not only are the $\mathrm{CO}$ concentrations reduced but also the maximum $\mathrm{CO}$ is shifted to earlier in the year to coincide with the $\mathrm{OH}$ minimum. At Whistler, the annual maxima occur in February or March except for 2003, a year with high Asian biomass burning influence (van der Werf et al., 2006), when the maximum was in April. The variation in monthlyaveraged $\mathrm{CO}$ from year to year is lowest in February-March (9-12 ppbv) and highest in May (52 ppbv). Highest CO mixing ratios were observed throughout fall 2002 and springsummer 2003 but did not continue through fall 2003. 
Autumn 2002 and spring-summer 2003 were periods of highest $\mathrm{CO}$ anomaly at Whistler Peak; mixing ratios averaged $21 \%$ higher in September-October 2002 and $25 \%$ in April-August 2003 than the corresponding mean values for all five years. Anomalously high CO during these months has been reported from other Northern Hemisphere sites and is attributed to Siberian biomass burning (BB) during the summers of 2002 and 2003 (Yurganov et al., 2005; Jaffe et al., 2004). The anomalies in Northern Hemisphere boundary layer stations calculated relative to 2001-2002 values were a maximum of $35 \%$ in 2002 and $36 \%$ in 2003 compared with total column anomalies of $19 \%$ in 2002 and $25 \%$ in 2003 (Yurganov et al., 2005). The CO anomaly is not observed through the fall of 2003. The maxima in Siberian biomass burning emissions (van der Werf et al., 2006) were in August of 2002 and in May of 2003. The timing of these BB maxima are consistent with the $\mathrm{CO}$ anomalies at Whistler Peak, that is the effect of the late summer $2002 \mathrm{BB}$ maximum was observed through fall 2002 whereas the May 2003 BB maximum strongly influenced the spring.

Figure $4 \mathrm{~b}$ shows the frequency distributions of $\mathrm{CO}$ during June to August 2002 to 2006. In 2003, the entire distribution is shifted higher by approximately $20-25$ ppbv; in other years, the background $\mathrm{CO}$ values are generally similar $\left(10^{\text {th }}\right.$ percentiles for June-August are 99, 121, 94, 93, 94 ppbv for 2002-2006 respectively). The 2004 and 2006 spring and summer seasons had two modes at 110 and $130 \mathrm{ppbv}$ for the Jun-Aug period. The summer of 2004 was a high year for biomass burning in Alaska and Yukon Territory (van der Werf et al., 2006) and these fires have been shown to influence pollution levels in eastern North America and across the Atlantic (Pfister et al., 2006; Val Martin et al., 2006; Lapina et al., 2006) A combination of regional fires in British Columbia and the Alaskan and Yukon fires affected the CO mixing ratios seen at Whistler site in June through August 2004. These varying sources are discussed in the following sections.

\subsection{Effect of trans-Pacific transport}

The influence of various source and transport regions on $\mathrm{O}_{3}$ and $\mathrm{CO}$ measured at Whistler was investigated by segregating the data by $750 \mathrm{hPa}$ air mass back trajectories as calculated by the CMC trajectory model (D'Amours and Page, 2001). Boxes were defined to represent different air mass origins and pathways (Fig. 5). $\mathrm{CO}$ and $\mathrm{O}_{3}$ data were averaged over 6-hour periods centered on the arrival time of the air mass. To reduce possible local boundary layer influences and problems with trajectories over mountainous terrain, $\mathrm{CO}$ and $\mathrm{O}_{3}$ associated with trajectories having spent more than 12 of their final $48 \mathrm{~h}$ at altitudes less than $1000 \mathrm{~m}$ a.s.l. were eliminated from the analysis. The defined boxes are of different sizes and thus there is an inherent bias in the total amount of time a given trajectory can spend in a particular box. Thus the assignment of a six-hour mean $\mathrm{CO}$ or $\mathrm{O}_{3}$ value to a back

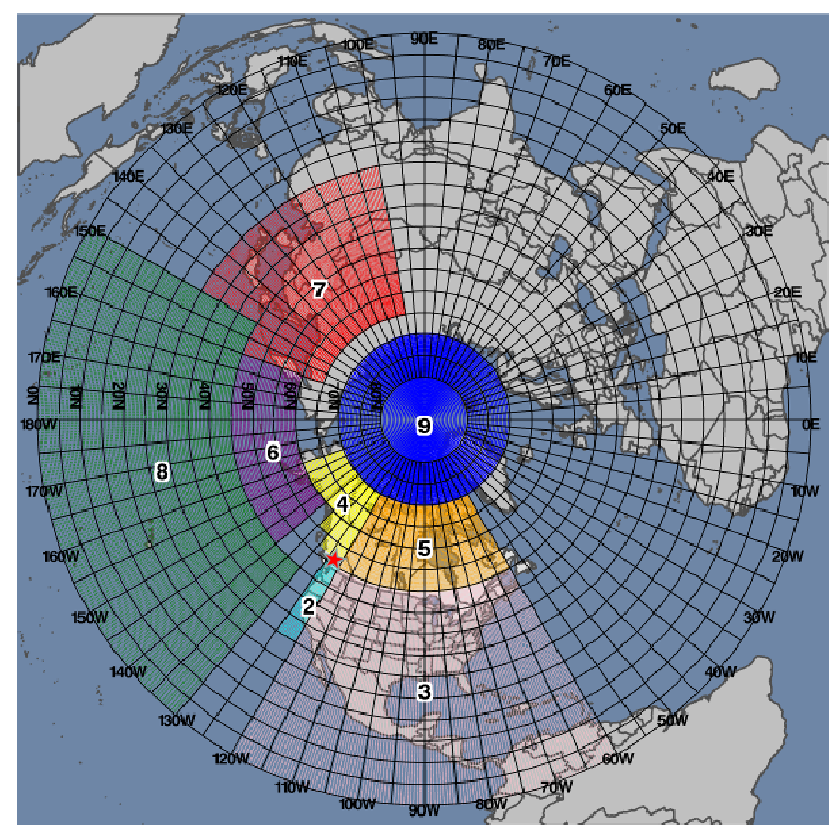

Fig. 5. Locations of boxes defined for trajectory analysis. Boxes 25 represent North American influence; Boxes 6-7 represent Asian sources and trans-Pacific transport; Box 8 is the southern part of the North Pacific.

trajectory box is based on the residence time of the trajectory above a seasonally varying threshold residence time. For a given trajectory, at least $40 \%$ of the total residence time within a box region was determined as the optimal threshold. This threshold maximized the largest number of samples that could be kept for subsequent analyses and minimized the number of trajectories that were attributed to multiple box regions. Mean values of $\mathrm{O}_{3}$ and $\mathrm{CO}$ calculated for threshold values of $20 \%$ and $60 \%$ of the seasonally varying maximum are also shown for comparison.

Seasonal and interannual differences in the relative transport through the boxes reflect the variations in the synoptic scale climatology controlled by the Aleutian Low and the Pacific High. In winter, zonal flow is generally stronger and the Aleutian low results in a southwesterly component of the flow over $\mathrm{BC}$ while in summer, the intensifying $\mathrm{Pa}-$ cific High causes a more northwesterly flow over the south coast of British Columbia (Klock and Mullock, 2001). Normalized transport in representative boxes is shown in Fig. 6 along with the 5-yr mean $\mathrm{CO}$ at Whistler Peak. The frequency of trajectories originating in the Asian box (Box 7) is highest during (November-April) and lowest during (MayAugust) reflecting the stronger zonal transport during winter and spring. Transport via the northerly route and passing over Northern British Columbia and Alaska is stronger in spring and early summer (Box 4). In contrast, air masses passing along the west coast of the US (Box 2, not shown) are more often seen during summer. The frequency of transport 


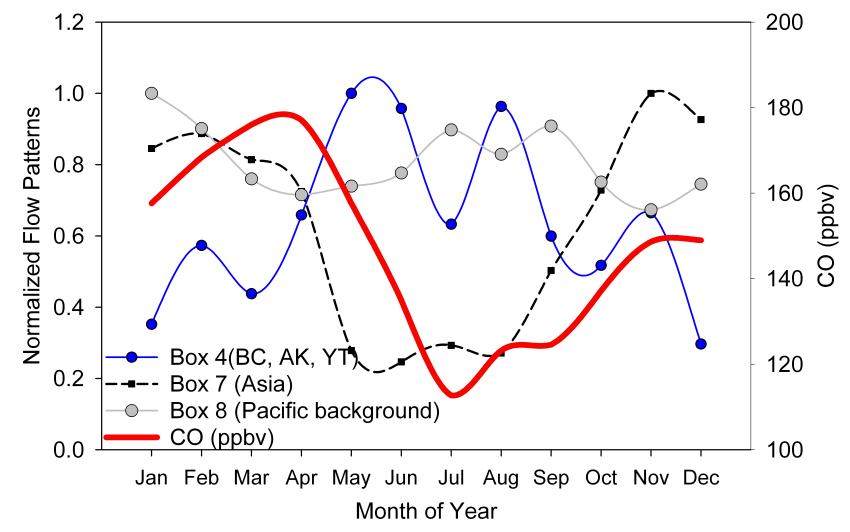

Fig. 6. Normalized frequency of transport through boxes defined in Fig. 5 as a function of month of year.

to the site from the South part of the North Pacific (Box 8) remains relatively constant throughout the entire year.

Mean values of $\mathrm{O}_{3}$ and $\mathrm{CO}$ for Boxes 7 and 8 are given in Figs. 7a and b. Box 7 represents air masses with Asian origin and trans-Pacific transport (t-P) and the Box 8 represents the south part of the North Pacific, also defined here as representing the Pacific background. For $\mathrm{O}_{3}$, differences between Asian-influenced (Box 7) and background (Box 8) air are less than $1.5 \mathrm{ppbv}$ during November-January and JulyAugust. The greatest differences are seen in March-June and September-October with an average of $6 \pm 2$ ppbv more $\mathrm{O}_{3}$ in t-P air masses above the clean background for the entire March-June period. For CO, mixing ratios in Boxes 7 and 8 are similar during July and August, but for all other months, the $\mathrm{CO}$ in t-P air masses ranges from 4 to $25 \mathrm{ppbv}$ more than is seen in the clean Pacific air masses. In MarchJune, the mean CO enhancement is $16 \pm 2$ ppbv. The similarities in Boxes 7 and 8 in Jul-Aug may be a reflection of the reduced zonal transport. The $\mathrm{CO}$ and $\mathrm{O}_{3}$ values for Boxes 7 and 8 in July and August are lower than the mean values for all air masses.

The highest values of $\mathrm{CO}$ and $\mathrm{O}_{3}$ in summer are dominated by local and regional events with transport from the North American boxes, i.e. either up the coast from California or from the north and influenced by Alaska, Yukon or Northern British Columbia. This may be due both to the influence of forest fires or also of urban centers south of Whistler, throughout the Pacific Northwest and northern California. The next section investigates the relative influences of trans-Pacific transport or biomass burning during the spring and summer.

\subsection{Effect of North American boreal fires}

Influence of trans-Pacific transport and of North American sources varies from spring to summer as well as from year to year. Data from May and August are shown as representative of spring transport and biomass burning seasons respectively
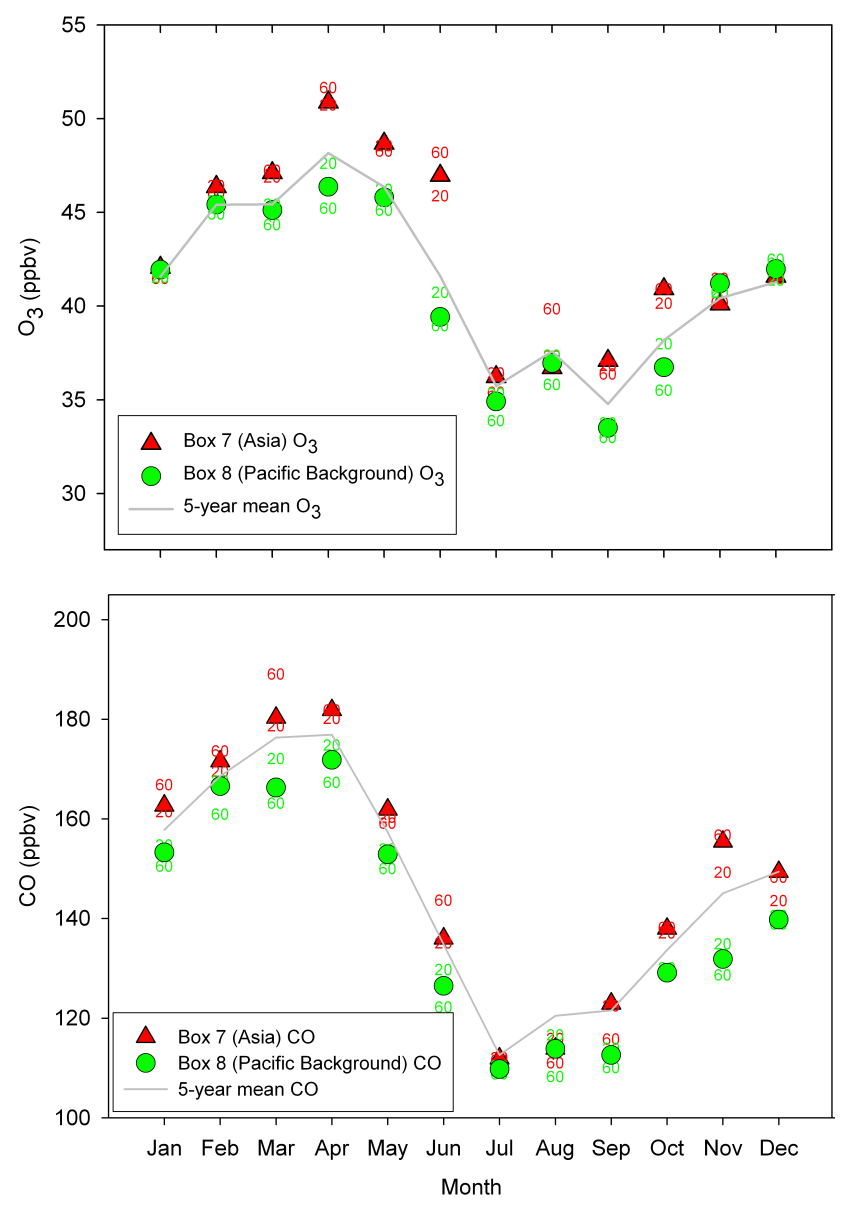

Fig. 7. (a) Mean values of $\mathrm{O}_{3}$ associated with transport through Boxes 7 and 8 as a function of month of year. Boxes are assigned based on $40 \%$ of the seasonally varying maximum time in a box. For comparison, mean values for $20 \%$ and $60 \%$ of time in a box are also shown. (b) As in (a) but for CO.

(Fig. 8). The pattern for June is similar to May while the July pattern is similar to August. The $\mathrm{O}_{3}$ and $\mathrm{CO}$ enhancements for trans-Pacific (t-P) (Boxes 6, 7) or North American (NA) (Boxes 2, 3, 4, 5) air masses are presented relative to the Pacific background (Box 8) for 2002-2006. The absolute enhancements will depend on the values chosen to represent this background and air masses from Box 8 may be a conservatively high estimate based on the comparison with the 30th percentiles of the data (Table 2). In May, there is no significant difference between $\mathrm{O}_{3}$ in t-P or NA air masses in 20022005 (i.e. no significant difference and each $0-6$ ppbv higher than background, Fig. 8a). In 2006, the t-P air masses averaged approximately 6 ppbv above the background whereas the NA boxes were lower than background by 9 ppbv. Background values may be overestimated for this year resulting in this negative $\Delta \mathrm{O}_{3}$ (NA) and a lower background would result also in increased $\Delta \mathrm{O}_{3}(\mathrm{tP})$. During the spring 2006 INTEXB period (Leaitch et al., 2009; Walker et al., 2010) ozone 

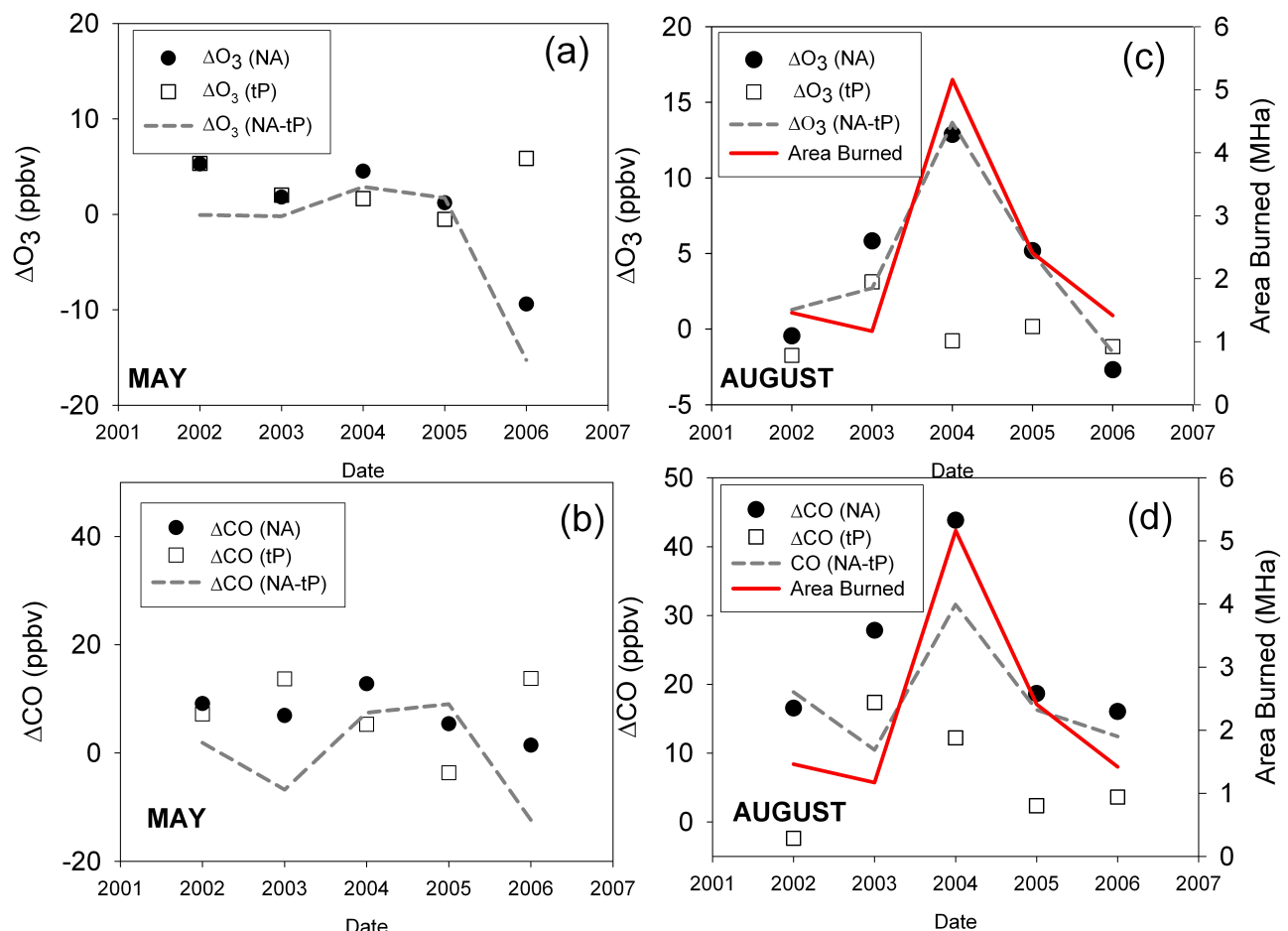

Fig. 8. (a) Mean $\mathrm{O}_{3}$ mixing ratios in North American and in trans-Pacific boxes minus the clean Pacific background in May 2002-2006. The dashed line shows the difference between NA and t-P $\mathrm{O}_{3}$; (b) as in Fig. 8a but for CO; (c) as in (a) but shows $\Delta \mathrm{O}_{3}$ for August; (d) as in (c) but shows $\triangle \mathrm{CO}$ for August. The red line shows the sum of western North America area burned as reported in Table 2.

Table 1. Estimates of area burned in western North America and for the Russian Federation for 2002-2006. (Sources: US National Interagency Fire Center; Canadian Interagency Forest Fire Centre; Goldammer et al., 2007).

\begin{tabular}{rrrrrrrrr}
\hline & $\begin{array}{r}\text { British } \\
\text { Columbia }\end{array}$ & $\begin{array}{r}\text { Yukon } \\
\text { Territory }\end{array}$ & $\begin{array}{r}\text { North West } \\
\text { Territories }\end{array}$ & Alberta & Alaska & US Northwest ${ }^{1}$ & $\begin{array}{r}\text { US Northern } \\
\text { Rockies }^{2}\end{array}$ & $\begin{array}{r}\text { Russian } \\
\text { Federation }\end{array}$ \\
\hline & $\mathrm{Ha}$ & $\mathrm{Ha}$ & $\mathrm{Ha}$ & $\mathrm{Ha}$ & $\mathrm{Ha}$ & $\mathrm{Ha}$ & $\mathrm{Ha}$ & $\mathrm{MHa}$ \\
2002 & 8586 & 35669 & 27089 & 496515 & 880865 & 446648 & 153909 & 10.6 \\
2003 & 264736 & 48785 & 127821 & 74874 & 226354 & 145973 & 479700 & 17.9 \\
2004 & 220516 & 1720324 & 515621 & 236090 & 2689528 & 49629 & 27035 & 4.4 \\
2005 & 34664 & 170694 & 218133 & 60763 & 1796862 & 138030 & 232197 & 9.3 \\
2006 & 139201 & 95034 & 53398 & 118762 & 107754 & 386851 & 920240 & 13.1 \\
\hline
\end{tabular}

${ }^{1}$ Northwest is Oregon and Washington; ${ }^{2}$ US Northern Rockies is the sum of Idaho, Montana, North Dakota, and Wyoming.

enhancements of about 10 ppbv were estimated in Asian air masses arriving at Whistler. For CO (Fig 8b), with the exception of 2005, values in t-P or NA air masses were 5-14 ppbv higher than the background but this enhancement was not consistently dominated by one sector or the other. In 2002, 2004, and 2005 the North American influence was greater but in 2003 and 2006, CO was higher in t-P influenced air masses.

During the summer biomass burning period (as represented by August), the amount of ozone in the t-P boxes relative to background is in the \pm 2 ppbv range with the greatest enhancement of 3 ppbv seen in August 2003 (Fig. 8c). For the NA boxes, however, the greatest ozone enhancement relative to the background occurred in 2004 at about 13 ppbv, followed by 5-6 ppbv increases in 2003 and 2005. Enhancement of $\mathrm{CO}$ in NA air masses is always greater than in t$\mathrm{P}$ air masses (Fig. 8d). For August 2004, the corresponding enhancement in CO was 43 ppbv for the North American air masses whereas the trans-Pacific enhancement was only 12 ppbv.

These largest summer increases in $\mathrm{O}_{3}$ and $\mathrm{CO}$ are attributed to the North American boreal fires. Total estimates of area burned (Table 1; Sources: US National Interagency Fire Center; Canadian Interagency Forest Fire Centre) in 
Table 2. Monthly background values defined for $\mathrm{CO}$ and $\mathrm{O}_{3}$ as average mixing ratios from Box 8 . The 30th percentiles of all data are also shown in parentheses.

\begin{tabular}{|c|c|c|c|c|c|c|c|c|c|c|}
\hline & \multicolumn{5}{|c|}{$\mathrm{O}_{3}$} & \multicolumn{5}{|c|}{$\mathrm{CO}$} \\
\hline & 2002 & 2003 & 2004 & 2005 & 2006 & 2002 & 2003 & 2004 & 2005 & 2006 \\
\hline May & $43(42)$ & $48(46)$ & 45 (44) & $44(42)$ & $48(43)$ & $146(140)$ & 184 (179) & $150(148)$ & $142(132)$ & 142 (149) \\
\hline June & $39(38)$ & $43(39)$ & $40(37)$ & $36(34)$ & $40(38)$ & $124(123)$ & 156 & $130(125)$ & 109 (112) & 114 (123) \\
\hline July & $37(32)$ & $38(33)$ & $36(33)$ & $29(29)$ & $34(29)$ & $118(102)$ & $132(126)$ & $109(106)$ & $90(93)$ & $100(94)$ \\
\hline August & $37(31)$ & $38(37)$ & $35(30)$ & $37(33)$ & $38(34)$ & 118 (104) & 134 (132) & 97 (95) & 117 (109) & 104 (107) \\
\hline $\begin{array}{l}\text { Annual Mean } \\
\text { (Median) }\end{array}$ & $41(41)$ & $43(43)$ & $41(42)$ & $41(40)$ & $42(41)$ & $153(151)$ & $160(160)$ & 141 (143) & 138 (138) & 135 (137) \\
\hline
\end{tabular}

western North America are also plotted on Fig. 8c-d. Fire influence was low in 2002; the most notable western regional fires were in late spring and early summer in Alberta. Influence from this sector is uncommon at Whistler but elevated levels of $\mathrm{CO}$ and $\mathrm{O}_{3}$ were observed with northeasterly flow in mid-June 2002. As noted previously, 2003 was a high year of boreal fires in Siberia which resulted in increased $\mathrm{O}_{3}$ and $\mathrm{CO}$ at Whistler. However, because the entire $\mathrm{CO}$ distribution was shifted higher in 2003, the incremental differences in average NA CO above the defined background mixing ratios (Table 2) were not as great as those in 2004-2005. The most notable North American forest fires over these latter years were those in Alaska (AK) and Yukon Territory (YT) in summer of 2004 and in AK in 2005. The 2004 AK and YT fires were the largest on record in terms of area burned (Global fire Monitoring Centre; http://www.fire.uni-freiburg.de/) and they influenced much of Eastern North America (Pfister et al., 2006) and across the Atlantic (Honrath et al. 2006; Val Martin et al., 2006). In summer 2005, the total area burned in British Columbia was only about $50 \%$ of the 10 -yr average but it was once again another very active burning season in Alaska; the estimated area burned reached almost $70 \%$ of the 2004 season. In 2006, fire plumes from California and the US Northern Rockies were both observed at Whistler.

The August enhancement in both $\mathrm{CO}$ and $\mathrm{O}_{3}$ for North American air masses relative to the background, co-varies with the total area burned (Fig. 8c-d; see solid circles and red line). For several sites in western North America, Jaffe et al. (2008) have shown an increase in summer mean ozone (1998-2004) with area burned in a 10x10 degree region around each measurement site. This relationship is also evident for the Whistler site and relates increases in ozone to $\mathrm{CO}$, a tracer for combustion. Boreal fires, in addition to their significance in controlling the $\mathrm{CO}$ budget, are substantial sources of NOx and NMHCs (Wotawa et al., 2001) and thus additional precursors for ozone formation. These emissions have been shown to have an effect on regional ozone concentrations (Jaffe et al., 2004; Val Martin et al., 2006; Honrath et al., 2004; DeBell et al., 2004; Bertschi and Jaffe, 2005). Pfister et al. (2006) estimated the ozone production from Alaskan and Northern Canadian wildfires during summer 2004 to increase the ozone burden from the surface to $300 \mathrm{hPa}\left(50-70^{\circ} \mathrm{N}, 180^{\circ} \mathrm{E}-60^{\circ} \mathrm{W}\right)$ by approximately $7-9 \%$. The ozone increase at Whistler for August 2004, is about 35$40 \%$ over the background. This analysis does not separate any NA anthropogenic influences from forest fire sources, nor does it consider any changes in North American anthropogenic emissions from year to year.

\subsection{Relationship between ozone and CO}

The relationship between $\mathrm{O}_{3}$ and $\mathrm{CO}$ has been examined at various background sites to estimate the degree of photochemical ozone production in the atmosphere (e.g Parrish et al., 1993; Parrish et al., 1998). The close covariance of $\mathrm{O}_{3}$ and $\mathrm{CO}$ at Whistler is shown in Fig. 3c with the springtime maxima in $\mathrm{CO}$ sometimes preceding that for $\mathrm{O}_{3}$. For several North Atlantic sites (Parrish et al., 1998) $\mathrm{O}_{3}$ and $\mathrm{CO}$ were positively correlated in summer with $\mathrm{O}_{3}$ versus $\mathrm{CO}$ slopes of approximately 0.3-0.4. Honrath et al. (2004) analyzed 2001 and $2003 \mathrm{O}_{3}$ and $\mathrm{CO}$ from the high altitude Azores site (Pico) and found slopes often closer to unity, in part attributed to longer transport times from North American source regions to the Azores. On the west coast of NA, Weiss-Penzias et al. (2004) found slopes of about $0.2-0.3$ for $\mathrm{O}_{3}$ to $\mathrm{CO}$ relationship in summer 2001. At Whistler, the slopes of the hourly $\mathrm{O}_{3}$ to $\mathrm{CO}$ relationship as a function of month are shown in Fig. 9. The seasonality of the slopes introduced by Parrish et al., 1998 is also seen at Whistler, with positive slopes in spring and summer and negative slopes in winter. Summertime (JJA) slopes of $\mathrm{O}_{3}$ to $\mathrm{CO}$ at Whistler range from a low of 0.21 in Aug 2005 to 0.62 in July 2005 (average slope JJA, 2002-2006 $=0.45$ ). The reduction in slope from July to Aug 2005 is primarily driven by the mixed influence from CO produced by regional and local forest fires in Aug 2005 and their impact at the site. The correlations between $\mathrm{O}_{3}$ and $\mathrm{CO}$ at Whistler ( $R^{2}$ in JJA of 0.1 to 0.6$)$, however, are lower than those found by Parrish et al. (1998) $\left(R^{2}\right.$ of 0.5 to 0.7 ) and closer to those observed at Cheeka Peak (maximum $R^{2} \sim 0.4$, Weiss-Penzias et al., 2004). This greater degree of 


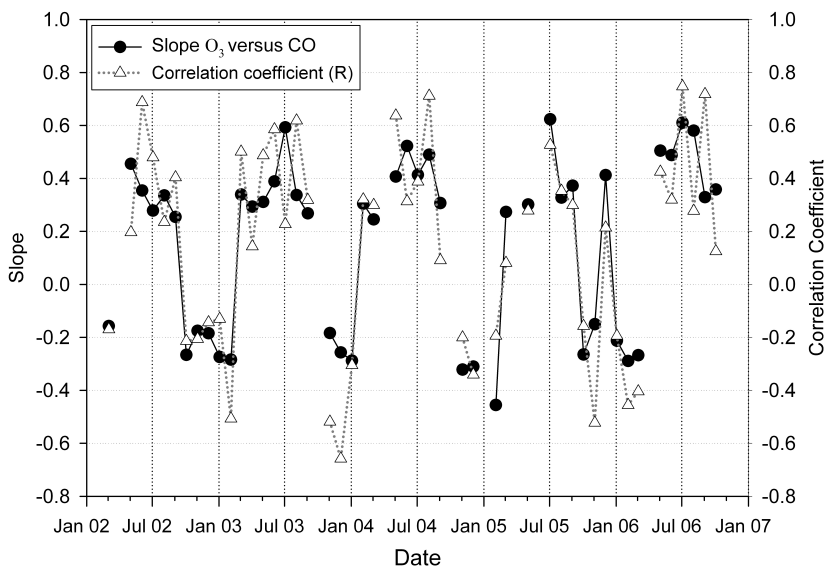

Fig. 9. Time series of slope and coefficient of determination for hourly $\mathrm{O}_{3}$ versus $\mathrm{CO}$ relationships for each month based on the reduced major axis regression. The slopes are not shown when the $\mathrm{p}$-value of the regression is less than 0.05 .

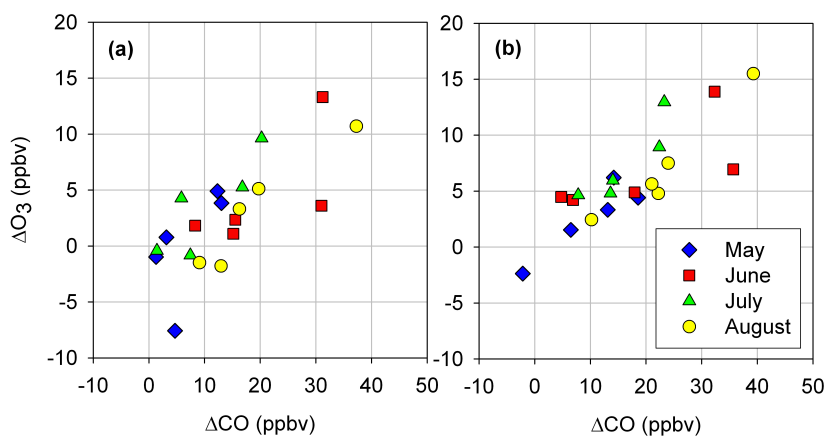

Fig. 10. Scatter plot of $\Delta \mathrm{O}_{3}$ versus $\Delta \mathrm{CO}$ on a monthly basis for 2002-2006 where $\Delta \mathrm{O}_{3}$ and $\Delta \mathrm{CO}$ are the differences between the North American averages and the background values defined as the average from (a) Box 8 and (b) the 30th percentile for all data each month.

scatter between $\mathrm{O}_{3}$ and $\mathrm{CO}$ in the Whistler measurements may be due to the proximity of regional boreal fires and the variation in the chemical processing time of the measured air masses.

The enhancement ratios of $\mathrm{O}_{3}$ and $\mathrm{CO}$ above background values over specific periods also describe the regional $\mathrm{O}_{3}$ production relative to precursor emissions. The ratios will depend on the values chosen to represent the background. Honrath et al. (2004) used the low modes of the $\mathrm{CO}$ and $\mathrm{O}_{3}$ distributions; Pfister et al. (2008) chose average values of a non-fire impacted air masses; Val Martin et al. (2008) used the 20th percentile of all data for each season and year. The enhancement of $\mathrm{O}_{3}$ relative to $\mathrm{CO}$ in NA air masses is shown in Fig. 10 where the background air masses for each month are defined here as the $\mathrm{O}_{3}$ and $\mathrm{CO}$ mixing ratios in (a) Box 8 , and (b) the 30th percentile of all data (Table 2). Although there is scatter, Fig. 10 shows largest enhancement of $\mathrm{O}_{3}$ and
$\mathrm{CO}$ in August relative to May. For months when $\Delta \mathrm{CO}$ was greater than $10 \mathrm{ppbv}$, ratios of $\Delta \mathrm{O}_{3}$ to $\Delta \mathrm{CO}$ range from about 0.2 to 0.6 with the median value of 0.31 . The lowest ratio was in June 2004 when the site was influenced by a regional fire. This enhancement ratio is in the range of that calculated in Pfister et al. (2006), of approximately $0.26 \mathrm{ppbv} / \mathrm{ppbv}$ downwind of the 2004 fires. Mauzerall et al. (1998) reported different $\Delta \mathrm{O}_{3} / \Delta \mathrm{CO}$ ratios depending on the age of the air mass ranging from 0.15 to 0.74 for fresh to aged plumes during the TRACE-A experiment. While $\mathrm{CO}$ is emitted from fires, $\mathrm{O}_{3}$ is produced from the fire-emitted precursors as the air mass moves downstream. Pfister et al. (2008) found that the areas of maximum $\mathrm{O}_{3}$ and $\mathrm{CO}$ are not necessarily co-located. The relationship between $\mathrm{O}_{3}$ and $\mathrm{CO}$ varied and depended on the location of the fire source area relative to Whistler. Selected events observed at Whistler in summer 2005, 2006 are shown in Fig. 11 to illustrate the variability in the $\mathrm{O}_{3}$ to $\mathrm{CO}$ relationship at Whistler. For all of these events, the rise in $\mathrm{CO}$ was greater than $20 \mathrm{ppbv}$ above background values. Source regions are identified based on back trajectories and satellite analyses NOAA Hazard Mapping System Fire Analysis (http://www.ospd.noaa.gov/ml/land/hms.html). For these examples, fire source areas were southern British Columbia, northern Washington State, Alaska, Yukon and California.

During 9-12 August 2005 (Fig. 11a), $\mathrm{CO}$ and $\mathrm{O}_{3}$ are anti correlated with a slope of $-0.14\left(R^{2}=0.66\right)$; for August 1417 (not shown), the period of maximum CO ( $440 \mathrm{ppbv})$, there is a slight positive slope (0.07) although the correlation is weak $\left(R^{2}=0.19\right)$. Figure 11 also shows $750 \mathrm{hPa}$ back trajectories superimposed on analyzed smoke fields from the NOAA Hazard Mapping System Fire Analysis. In the 9-12 August period, the site still appears to be in smoke. For the next period (24-27 August 2005), the air mass was coming from Alaska but the area directly over Whistler appears free of smoke (Fig. 11b). In this period, $\mathrm{O}_{3}$ and $\mathrm{CO}$ were positively correlated (slope of $0.29, R^{2}=0.53$ ).

The final example (Fig. 11c) is from the end of the 2006 fire season. For this case, (1-6 September 2006), the source of this fire was southwestern US. Over 1-6 September period, CO rose from a baseline value of $\sim 110 \mathrm{ppbv}$ to peak at $248 \mathrm{ppbv}$ on 4 September. Ozone peaked at $65 \mathrm{ppbv}$, approximately $35 \mathrm{ppbv}$ above the baseline level of $30 \mathrm{ppbv}$. The calculated $\mathrm{O}_{3}$ to $\mathrm{CO}$ ratio for this episode is 0.25 .

Although these examples (Fig. 11) are just a subset of the fire events influencing the Whistler high elevation site, they illustrate the diversity in the $\mathrm{CO}$ to $\mathrm{O}_{3}$ relationship with an anti-correlation between $\mathrm{O}_{3}$ and $\mathrm{CO}$ in fresh plumes (or plumes with a major source close to the sampling site); slight positive correlations in plumes accompanied by smoke but with estimated travel times of 1-2 days from the source, and positive slopes of approximately 0.25 to $0.3 \mathrm{ppbv} / \mathrm{ppbv}$ for the plumes estimated with travel times of 3-5 days. 

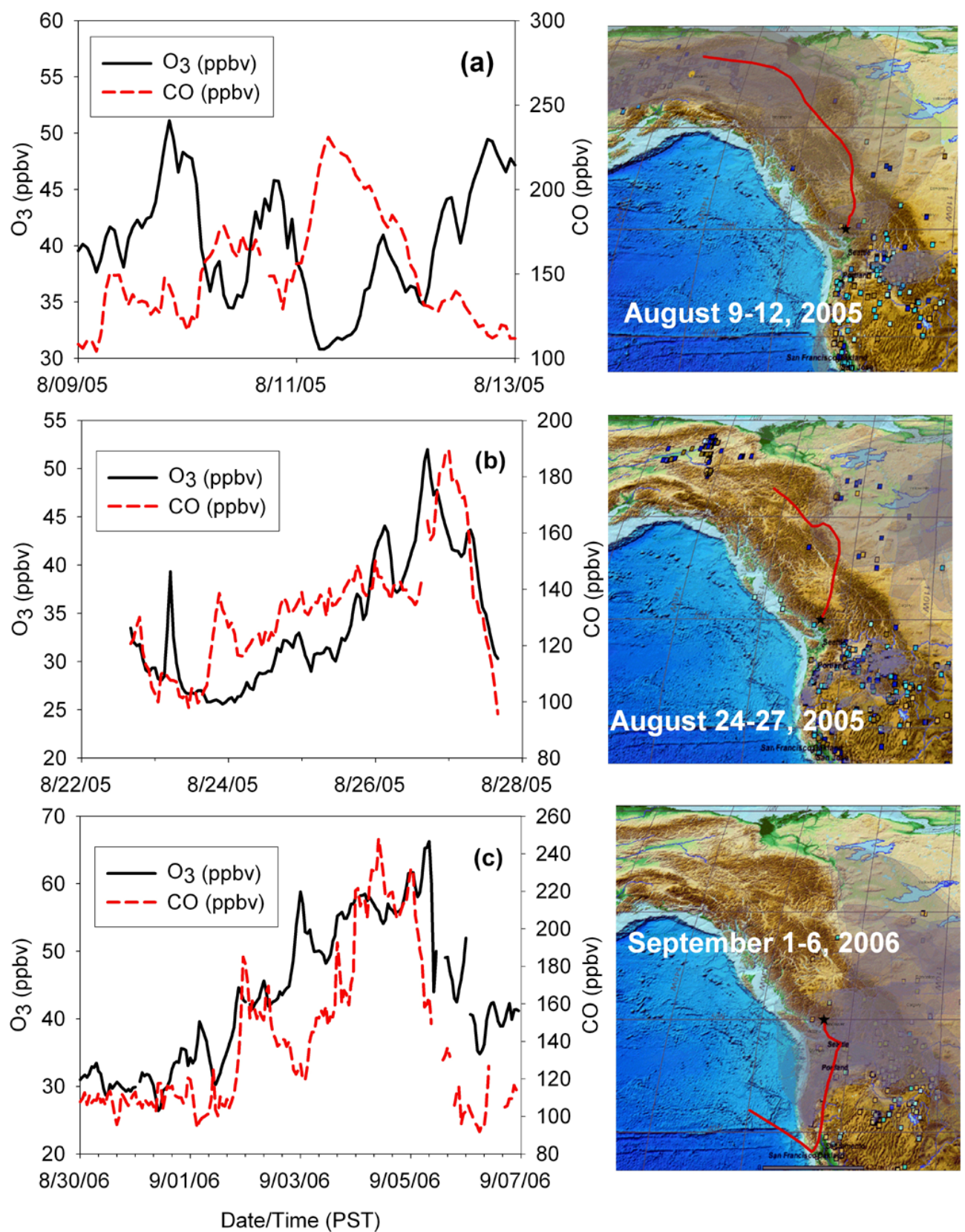

Fig. 11. Time series of $\mathrm{O}_{3}$ and $\mathrm{CO}$ mixing ratios and analyzed smoke from the NOAA emission viewer for (a) 9-13 August 2005; (b) 22-27 August 2005; (c) 31 August-6 September 2006. The panels on the right show analyzed smoke from the NOAA emission viewer with the $750 \mathrm{hPa}$ back trajectory from Whistler overlaid.

\section{Summary}

Year-round measurements of $\mathrm{CO}$ and $\mathrm{O}_{3}$ from the Whistler high elevation site from 2002 to 2006 provide lower free tropospheric mixing ratios on Canada's west coast. $\mathrm{CO}$ exhibits a seasonal cycle with a spring maximum and summer minimum similar to other background sites throughout the Northern Hemisphere. $\mathrm{O}_{3}$ exhibits a similar annual variation with an overall pattern like that at the marine boundary layer sites on the US west coast such as Trinidad Head and Cheeka Peak. The annual variation differs from several inland US high elevation sites and also from the $2 \mathrm{~km}$ ozonesonde mixing ratios from Trinidad Head all of which exhibit a broad spring-summer maximum. The overall pattern is comparable to ozonesonde data taken from Kelowna, a location $300 \mathrm{~km}$ to the east of Whistler although mean summer mixing ratios were 6-7 ppbv lower than the Kelowna data. $\mathrm{O}_{3}$ mixing ratios were higher at Whistler than at the marine boundary 
layer sites by 3-15 ppbv throughout the year. The absence of the summer shoulder of ozone at Whistler could possibly be attributed to boundary layer influences or may also be the absence of regional pollution which may play a more dominant role at other elevated sites. A boundary layer influence is observed at Whistler during warmer months throughout the daytime hours. The maximum diurnal cycle for $\mathrm{O}_{3}$ is in JJA and found to be $3.5 \mathrm{ppbv}$ about a daily mean.

Highest monthly-averaged CO was found in fall 2002 and spring 2003, coincident with increased CO found throughout the Northern Hemisphere as a result of elevated burning in Siberia. Overall values were approximately $20-25 \mathrm{ppbv}$ higher in 2003, values about $25 \%$ above the five year mean.

The influence of different transport and source regions on measured values was examined through a back trajectory analysis. Largest differences in $\mathrm{CO}$ and $\mathrm{O}_{3}$ for air masses originating in Asia relative to the south part of the north Pacific were in fall through spring. The mean enhancements in $\mathrm{CO}$ and $\mathrm{O}_{3}$ for March-June were 11 ppbv and 4 ppbv respectively. During summer, very little difference was observed between trans-Pacific air masses and the clean background and highest $\mathrm{CO}$ and $\mathrm{O}_{3}$ mixing ratios were found for air masses originating in North America. During the May transport season, the relative importance of North American or trans-Pacific contributions to increased $\mathrm{CO}$ and $\mathrm{O}_{3}$ varied from year to year. In August, enhancements in $\mathrm{CO}$ and $\mathrm{O}_{3}$ in North American air masses were generally greater than in trans-Pacific air masses. The greatest effects were observed in 2004 and 2005 for both $\mathrm{CO}$ and $\mathrm{O}_{3}$. This corresponded to higher estimates of forest fires throughout the western US and Canada.

Monthly correlations of $\mathrm{O}_{3}$ with $\mathrm{CO}$ for 2002-2006 were positive in summer and negative in winter. In summertime, these slopes range from 0.21 to 0.62 with the lowest slope in 2005. Correlation coefficients were lower than those reported by Parrish et al. (1998) presumably because of the varying influence of regional forest fires and natural sources during summers at Whistler. The enhancement in $\mathrm{O}_{3}$ relative to $\mathrm{CO}$ was estimated for May-September by calculating the average $\mathrm{CO}$ and $\mathrm{O}_{3}$ above monthly background levels. For months when $\Delta \mathrm{CO}$ exceeded $10 \mathrm{ppbv}$, the enhancement ratios ranged from about 0.2 to $0.6 \mathrm{ppbv}_{\mathrm{ppbv}}{ }^{-1}$. Relationships between $\mathrm{O}_{3}$ and $\mathrm{CO}$ from individual summer periods from 2003-2006, all influenced by biomass burning, showed a range of slopes from less than zero to 0.4 .

The data show the importance of North American biomass burning on both the $\mathrm{CO}$ and $\mathrm{O}_{3}$ mixing ratios measured at this lower free-troposphere site. Although trans-Pacific transport plays a role during winter through spring, it is biomass burning that appears most important during summer in contributing to periods of elevated ozone above the hemispheric baseline. This important source needs to be carefully considered in the development and evaluation of ozone mitigation strategies for Canada's west coast.
Acknowledgements. Co-operation and support from the Environmental Management group of Whistler-Blackcomb is gratefully acknowledged. We thank the site operators, Juniper Buller and Anton Horvath, the maintenance staff, lift operators and members of ski patrol. We also thank Maurice Watt and Art Tham for technical support.

Edited by: J. G. Murphy

\section{References}

Ambrose, J. L., Reidmiller, D. R., and Jaffe, D. A.: Causes of high $\mathrm{O} 3$ in the lower free troposphere over the Pacific Northwest as observed at the Mt. Bachelor Observatory, Atmos. Environ., 45, 5302-5315, 2011.

Andreae M. O., Berresheim, H., Andreae, T. W., Kritz, M. A., Bates, T. S., Merrill J. T.: Vertical distribution of dimethylsulfide, sulfur dioxide, aerosol ions, and radon over the northeast Pacific Ocean, J. Atmos. Chem., 6, 149-173, 1988.

Andrews, E.,Ogren, J. A., Bonasoni, P., Marinoni, A., Cuevas, E., Rodriguez, S., Sun, J. Y., Jaffe, D. A., Fischer, E. V., Baltensperger, U., Weingartner, E., Collaud Cohen, M., Sharma, S., Macdonald, A. M., Leaitch, W. R., Lin, N.-H., Laj, P., Arsov, T., Kalapov, I., Jefferson, A., and Sheridan, P: Climatology of aerosol radiative properties in the free troposphere, Atmos. Res., 102, 365-393, doi:10.1016/jatmosres.2011.08.017, 2011.

Bailey, R., Barrie, L. A., Halsall, C. J., Fellin, P., Muir, D. C. G.: Atmospheric organochlorine pesticides in the western Canadian Arctic: Evidence of transpacific transport, J. Geophys. Res., 105, 11805-11811, 2000.

Bertschi I. T. and Jaffe, D. A.: Long-range transport of ozone, carbon monoxide, and aerosols to the NE Pacific troposphere during the summer of 2003: observations of smoke plumes from Asian boreal fires, J. Geophys. Res., 110, D05303, doi:10.1029/2004JD005135, 2005.

Chan, E. and Vet, R. J.: Baseline levels and trends of ground level ozone in Canada and the United States, Atmos. Chem. Phys., 10, 8629-8647, doi:10.5194/acp-10-8629-2010, 2010.

Cooper, O. R., Parrish, D. D., stohl, A., Trainer, M., Nedelec, P., Thouret, V., Cammas, J. P., Oltmans, S. J., Johnson, B. J., Tarasick, D., Leblanc, T., McDermid, I. S., Jaffe, D., Gao, R., Stith, S., Ryerson, T., Aikin, K., Campos, T., Weinheimer, A., and Avery, M. A.: Increasing springtime ozone mixing ratios in the free troposphere over western North America, Nature, 463, 344-348, 2010.

Crutzen, P. and Andreae, M. O.: Biomass burning in the tropics: Impact on atmospheric chemistry and biogeochemical cycles, Science, 250, 1669-1678, 1990.

Dalsoren, S. B., Eide, M. S., Myhre, G., Endressen, O., Isaksen, I. S. A., and Fuglestvedt, J. S.: Impacts of the Large Increase in International Ship Traffic 2000-2007 on Tropospheric Ozone and Methane, Environ. Sci. Technol., 44, 2482-2489, 2010.

D'Amours, R. and Page, P.: Atmospheric transport models for environmental emergencies. http://collaboration.cmc.ec.gc.ca/cmc/ cmoi/product_guide/docs/lib/model-eco_urgences_e.pdf, Canadian Meteorological Centre, Environment Canada, Montreal, Quebec, 7 pp., 2001.

DeBell L. J., Talbot, R. W., Dibb, J. E., Munger, J. W., Fischer, E. V., and Frolking, S. E.: A major regional air pollution 
event in the northeastern United States caused by extensive forest fires in Quebec, Canada, J. Geophys. Res., 109, D19305, doi:10.1029/2004JD004840, 2004.

Fiore, A. M., Jacob, D. J., Bey, I., Yantosca, R. M., Field, B. D., Fusco, A. C., and Wilkinson, J. G.: Background ozone over the United States in summer: Origin, trend, contribution to pollution episodes, J. Geophys Res., 107, 4275, doi:10.1029/2001JD000982, 2002.

Galanter, M., Levy, H., and Carmichael, G. R.: Impacts of biomass burning on tropospheric $\mathrm{CO}, \mathrm{NO}_{\mathrm{x}}$, and $\mathrm{O}_{3}$. J. Geophys. Res., 105, 6633-6653, 2000.

Gallagher, J. P., McKendry, I. G., Macdonald, A. M., and Leaitch, W. R.: Seasonal and Diurnal Variations in Aerosol Concentration on Whistler Mountain: Boundary Layer Influence and Synoptic Scale Controls, J. Appl. Meteorol. Clim., 50, 2210-2222, doi:10.1175/JAMC-D-11-028.1, 2011.

Goldammer, J. G., Sukhinin, A., and Davidenko, E. P.: International Forest Fire News (IFFN) No. 37 (June-December 2007, in prep.) Advance Publication of Wildland Fire Statistics for Russia 19922007, ISSN 1029-0864, 2007.

Harris, J. M., Oltmans, S. J., Dlugokencky, E. J., Novelli, P. C., Johnson, B. J., and Mefford, T.: An investigation into the source of the springtime tropospheric ozone maximum at Mauna Loa observatory, Geophys. Res. Lett., 25, 1895-1898, 1998.

Heald, C. L., Jacob, D. J., Fiore, A. M., Emmons, L. K., Gille, J. C., Deeter, M. N., Warner, J., Edwards, D. P., Crawford, J. H., Hamlin, A. J., Sachse, G. W., Browell, E. V., Avery, M. A., Vay, S. A., Westberg, D. J., Blake, D. R., Singh, H. B., Sandholm, S. T., Talbot, R. W., and Fuelberg, H. E.: Asian outflow and transPacific transport of carbon monoxide and ozone pollution: An integrated satellite, aircraft, and model perspective, J. Geophys. Res., 108(D24), doi:10.1029/2003JD003507, 2003.

Holloway, T., Levy, H., and Kasibhatla, P.: Global distribution of carbon monoxide, J. Geophys. Res., 105, 12123-12147, 2000.

Honrath, R. E., Owen, R. C., Val Martin, M., Reid, J. S., Lapina, K., Fialho, P., Dziobak, M. P., Kleissl, J., and Westphal, D. L.: Regional and hemispheric impacts of anthropogenic and biomass burning emissions on summertime $\mathrm{CO}$ and $\mathrm{O}_{3}$ in the North Atlantic lower free troposphere, J. Geophys. Res., 109, D24310, doi:10.1029/2004JD005147, 2004.

Hudman, R. C., Murray, L. T., Jacob, D. J., Millet, D. B., Turquety, S., Wu, S., Blake, D. R., Goldstein, A. H., Holloway, J., and Sachse, G. W.: Biogenic versus anthropogenic sources of CO in the United States, Geophys. Res. Lett., 35, L04801, doi:10.1029/2007GL032393, 2008.

Husar, R. B., Tratt, D. M., Schichtel, B. A., Falke, S. R., Li, F., Jaffe, D., Gasso, S., Gill, T., Laulainen, N. S., Lu, F., Reheis, M. C., Chun, Y., Westphal, D., Holben, B. N., Gueymard, C., McKendry, I., Kuring, N., Feldman, G. C., McClain, C., Frouin, R. J., Merrill, J., DuBlois, D., Vignola, F., Murayama, T., Nickovic, S., Wilson, W. E., Sassen, K., Sugimoto, N., and Malm, W. C.: Asian dust events of April 1998, J. Geophys. Res., 106, 18317-18330, 2001.

Jacob, D. J., Logan, J. A., and Murti, P. P.: Effect of rising Asian emissions on surface ozone in the United States, Geophys. Res. Lett., 26, 2175-2178, 1999.

Jaffe D., Anderson, T., Covert, D., Kothenruther, R., Trost, B. Danielson, J. Simpson, W. Berntsen, T., Karlsdottir, S., Blake, D., Harris, J., Carmichael, G., and Ino, I.: Transport of Asian pollution to North America, Geophys. Res. Lett., 26, 711-714, 1999.

Jaffe, D., McKendry, I., Anderson, T., and Price, H.: Six "new" episodes of trans-Pacific transport of air pollutants, Atmos. Environ., 37, 391-404, 2003.

Jaffe, D., Bertschi, I., Jaegle, L., Novelli, P., Reid, J.S., Tanimoto, H., Vingarzan, R., and Westphal, D.: Long-range transport of Siberian biomass burning emissions and impact on surface ozone in western North America, Geophys. Res. Lett., 31, L16106, doi:10.1029/2004GL020093, 2004.

Jaffe, D. and Ray, J.: Increase in surface ozone at rural sites in the western US, Atmos. Environ., 41, 5452-5463, 2007.

Jaffe, D., Chand, D., Hafner, W., Westerling, A., and Spracklen, D.: Influence of Fires on $\mathrm{O}_{3}$ Concentrations in the Western U.S., Environ. Sci. Technol., 42, 5885-5891, doi:10.1021/es800084k, 2008.

Jaffe, D.: Relationship between Surface and Free Tropospheric Ozone in the Western U.S., Environ. Sci. Technol., 45, 432-438, 2011.

Kleissl, J., Honrath, R. E., and Henriques, d. V.: Analysis and application of Sheppard's airflow model to predict mechanical orographic lifting and the occurrence of mountain clouds, J. Appl. Meteorol. Clim., 45, 1376-1387, 2006.

Kleissl, J., Honrath, R. E., Dziobak, M. P., Tanner, D., ValMartin, M., Owen, R. C., and Helmig, D.: Occurrence of upslope flows at the Pico mountaintop observatory: A case study of orographic flows on a small volcanic island, J. Geophys. Res., 112, D10S35, doi:10.1029/2006JD007565, 2007.

Klock, R. and Mullock, J.: The Weather of British Columbia Graphic Area Forecast 31, Nav Canada, 221 pp., 2001.

Kritz, M. A., LeRoulley, J. C., and Danielson, E. F.: The China clipper-fast advective transport of radon-rich air from the Asian boundary layer to the upper troposphere near California, Tellus, 42B, 46-61, 1990.

Lapina, K., Honrath, R. E., Owen, R. C., Val Martin, M., and Pfister, G.: Evidence of significant large-scale impacts of boreal fires on ozone levels in the midlatitude Northern Hemosphere free troposphere, Geophys. Res., Lett., 33, L10815, doi:10.1029/2006GL025878, 2006.

Leaitch, W.R., Macdonald, A. M., Anlauf, K. G., Liu, P. S. K., Toom-Sauntry, D., Li, S.-M., Liggio, J., Hayden, K., Wasey, M.A., Russell, L. M., Takahama, S., Liu, S., van Donkelaar, A., Duck, T., Martin, R. V., Zhang, Q., Sun, Y., McKendry, I., Shantz, N. C., and Cubison, M.: Evidence for Asian dust effects from aerosol plume measurements during INTEXB 2006 near Whistler, BC, Atmos. Chem. Phys., 9, 3523-3546, doi:10.5194/acp-9-3523-2009, 2009.

Liang, Q., Jaegle, L., Jaffe, D.A., Weiss-Penzias, P., Heckman, A., and Snow, J. A.: Long-range transport of Asian pollution to the northeast Pacific: Seasonal variations and transport pathways of carbon monoxide, J. Geopyhs. Res., 109, D23S07, doi:10.1029/2003JD004402, 2004.

Liang, Q., Jaegle, L., Hudman, R. C., Turquety, S., Jacob, D. J., Avery, M. A., Browell, E. V., Sachse, G. W., Blake, D. R., Brune, W., Ren, X., Cohen, R. C., Dibb, J. E., Fried, A., Fuelberg, H., Porter, M., Heikes, B. G., Huey, G., Singh, H. B., and Wennberg, P. O.: Summertime influence of Asian pollution in the free troposphere over North America, J. Geophys., Res., 112, D12S11, doi:10.1029/2006JD007919, 2007. 
Mauzerall, D. L., Logan, J. A., Jacob, D. J., Anderson, B. E., Blake, D. R., Bradshaw, J. D., Heikes, B., Sachse, G. W., Singh, H., and Talbot, B.: Photochemistry in biomass burning plumes and implications for tropospheric ozone over the tropical South Atlantic, J. Geophys. Res., 103, 8401-8423, 1998.

McKeen, S. A., Wotawa, G. Parrish, D. D., Holloway, J. S., Buhr, M. P., Hubler, G., Fehsenfeld, F. C., and Meagher, J. F.: Ozone production from Canadian wildfires during June and July of 1995, J. Geophys. Res., 107, 4192, doi:10.1029/2001JD000697, 2002.

McKendry, I. G., Hacker, J. P., Stull, R., Sakiyama, S., Mignacca, D., and Reid, K.: Long-range transport of Asian dust to the Lower Fraser Valley, British Columbia, Canada, J. Geophys. Res., 106, 18361-18370, 2001.

Novelli, P. C., Masarie, K. A., and Lang, P. M.: Distributions and recent changes of carbon monoxide in the lower troposphere, J. Geophys. Res., 103, 19015-19033, 1998.

Novelli, P. C., Masarie, K. A. Lang, P. M., Hall, B. D., Myers, R. C., and Elkins, J. W.: Reanalysis of tropospheric CO trends: effects of the 1997-1998 wildfires, J. Geophys Res., 108, 4464, doi:10.1029/2002JD003031, 2003.

Oltmans, S. J., Lefohn, A. S., Harris, J. M., and Shadwick, D. S.: Background ozone levels of air entering the west coast of the US and assessment of longer-term changes, Atmos. Environ., 42, 6020-6038, 2008.

Oltmans, S. J., Hofmann, D. J., Lathrop, J. A., Harris, J. M., Komhyr, W. D., and Kuniyuki, D.: Tropospheric ozone during Mauna Loa Observatory Photochemistry Experiment 2 compared to long-term measurements from surface and ozonesonde observations, J. Geophys. Res., 101, 14569-14580, 1996.

Parrish, D. D., Holloway, J. S., Trainer, M., Murphy, P. C., Fehsenfeld, F. C., Forbes, G. L.: Export of north American Ozone Pollution to the North Atlantic Ocean, Science, 259, 1436-1439, 1993.

Parrish, D. D., Trainer, M., Holloway, J. S., Yee, J. E., Warshawsky, M. S., Fehsenfeld, F., Forbes, G. L., and Moody, J. L.: Relationships between ozone and carbon monoxide at surface sites in the North Atlantic region, J. Geophys. Res., 103, 13357-13376, 1998.

Parrish, D. D., Millet, D. B., and Goldstein, A. H.: Increasing ozone in marine boundary layer inflow at the west coasts of North America and Europe, Atmos. Chem. Phys., 9, 1303-1323, doi:10.5194/acp-9-1303-2009, 2009.

Parrish, D. D., Aikin, K. C., Oltmans, S. J., Johnson, B. J., Ives, M., and Sweeny, C.: Impact of transported background ozone inflow on summertime air quality in a California ozone exceedance area, Atmos. Chem. Phys., 10, 10093-10109, doi:10.5194/acp10-10093-2010, 2010.

Pfister, G. G., Emmons, L. K., Hess, P. G., Honrath, R., Lamarque, J.-F., Val Martin, M., Owen, R. C., Avery, M. A., Browell, E. V., Holloway, J. S., Nedelec, P., Purvis, R., Ryerson, T.B., Sachse, G. W., and Schlager, H.: Ozone production from the 2004 North American boreal fires, J. Geophys. Res., 111, D24S07, doi:10.1029/2006JD007695, 2006.

Pfister G.G., Wiedinmyer, C., and Emmons, L.K.: Impacts of the fall 2007 California wildfires on surface ozone: Integrating local observations with global model simulations, Geophys. Res. Lett., 35, L19814, doi:10.1029/2008GL034747, 2008.

Reidmiller, D. R., Jaffe, D. A., Chand, D., Strode, S., Swartzendru- ber, P., Wolfe, G. M., and Thornton, J. A.: Interannual variability of long-range transport as seen at the Mt. Bachelor observatory, Atmos. Chem. Phys., 9, 557-572, doi:10.5194/acp-9-557-2009, 2009.

Simpson, I. J., Akagi, S. K., Barletta, B., Blake, N. J., Choi, Y., Diskin, G. S., Fried, A., Fuelberg, H. E., Meinardi, S., Rowland, F. S., Vay, S. A., Weinheimer, A. J., Wennberg, P. O., Wiebring, P., Wisthaler, A., Yang, M., Yokelson, R. J., and Blake, D. R.: Boreal forest fire emissions in fresh Canadian smoke plumes: C1-C10 volatile organic compounds (VOCs), $\mathrm{CO}_{2}, \mathrm{CO}, \mathrm{NO}_{2}$, $\mathrm{NO}, \mathrm{HCN}$ and $\mathrm{CH}_{3} \mathrm{CN}$, Atmos. Chem. Phys., 11, 6445-6463, doi:10.5194/acp-11-6445-2011, 2011.

Slowik, J. G., Stroud, C., Bottenheim, J. W., Brickell, P. C., Chang, R. Y.-W., Liggio, J., Makar, P. A., Martin, R. V., Moran, M. D., Shantz, N. C., Sjostedt, S. J., van Donkelaar, A., Vlasenko, A., Wiebe, H. A., Xia, A. G., Zhang, J., Leaitch, W. R., and Abbatt, J. P. D.: Characterization of a large biogenic secondary organic aerosol event from eastern Canadian forests, Atmos. Chem. Phys., 10, 2825-2845, doi:10.5194/acp-10-2825-2010, 2010.

Singh, H. B., Brune, W. H., Crawford, J. H., Flocke, F., and Jacob, D. J.: Chemistry and transport of pollution over the Gulf of Mexico and the Pacific: spring 2006 INTEX-B campaign overview and first results, Atmos. Chem. Phys., 9, 2301-2318, doi:10.5194/acp-9-2301-2009, 2009.

Stohl A., Eekhardt, S., Forster, C., James, P., and Spichtinger, N.: On the pathways and timescales of intercontinental air pollution transport, J. Geophys. Res, 107, 4684, doi:10.1029/2001JD001396, 2002.

Talbot, R. W., Dibb, J. E., Lefer, B. L., Bradshaw, J. D., Sandholm, S. T., Blake, D. R., Blake, N. J., Sachse, G. W., Collins Jr., J. E., Heikes, B. G., Merrill, J. T., Gregory, G. L., Anderson, B. E., Singh, H. B., Thornton, D. C., Bandy, A. R., and Pueschel, R. F.: Chemical characteristics of continental outflow from Asia to the troposphere over the western Pacific Ocean during FebruaryMarch 1994: Results from PEM-West B, J. Geophys. Res., 102, 28255-28274, 1997.

Tarasick, D. W. and Slater, R.: Ozone in the Troposphere: Measurements, Climatology, Budget, and Trends, Atmos.-Ocean, 46, 93-115, doi:10.3137/ao.460105, 2008.

Van der Werf, G. R., Randerson, J. T., Giglio, L., Collatz, G. J., Kasibhatla, P. S., and Arellano Jr., A. F.: Interannual variability in global biomass burning emissions from 1997 to 2004, Atmos. Chem. Phys., 6, 3423-3441, doi:10.5194/acp-6-3423-2006, 2006.

Val Martin, M., Honrath, R. E., Owen, R. C., Pfister, G., Fialho, P., and Barata, F.: Significant enhancements of nitrogen oxides, black carbon, and ozone in the North Atlantic lower free troposphere resulting from North American boreal wildfires, J. Geophys. Res., 111, D23S60, doi:10.1029/2006JD007530, 2006.

VanCuren, R. A. and Cahill, T. A.: Asian aerosols in North America: frequency and concentration of fine dust, J. Geophys. Res., 107, 4804, doi:10.1029/2002JD002204, 2002.

van Donkelaar, A., Martin, R. V., Leaitch, W. R., Macdonald, A. M., Walker, T. W., Streets, D. G., Zhang, Q., Dunlea, E. J., Jimenez, J. L., Dibb, J. E., Huey, L. G., Weber, R., and Andreae, M. O.: Analysis of aircraft and satellite measurements from the Intercontinental Chemical Transport Experiment (INTEX-B) to quantify long-range transport of East Asian sulfur to Canada, Atmos. Chem. Phys., 8, 2999-3014, doi:10.5194/acp-8-2999-2008, 
2008.

Vingarzen, R.: A review of surface ozone background levels and trends, Atmos. Environ., 38, 3431-3442, 2004.

Walker, T. W., Martin, R. V., van Donkelaar, A., Leaitch, W. R., Macdonald, A. M., Anlauf, K. G., Cohen, R. C., Bertram, T. H., Huey, L. G., Avery, M. A., Weinheimer, A. J., Flocke, F. M., Tarasick, D. W., Thompson, A. M., Streets, G. G., and Liu, X.: Trans-Pacific transport of reactive nitrogen and ozone to Canada during spring, Atmos. Chem. Phys., 10, 8353-8372, doi:10.5194/acp-10-8353-2010, 2010.

Weiss-Penzias, P., Jaffe, D. A., Jaegle, L., and Liang, Q.: Influence of long-range-transported pollution on the annual and diurnal cycles of carbon monoxide and ozone at Cheeka Peak Observatory, J. Geophys. Res., 109, D23S14, doi:1029/2004JD004505, 2004.

Weiss-Penzias, P., Jaffe, D. A., Swartzendruber, P., Dennison, J. B., Chand, D., Hafner, W., and Prestbo, E.: Observations of Asian air pollution in the free troposphere at Mount Bachelor Observatory during the spring of 2004, J. Geophys. Res., 111, D24301, doi:10.1029/2005JD006522, 2006.

Wotawa, G., Novelli, P. C., Trainer, M., and Granier, C.: Interannual variability of summertime $\mathrm{CO}$ concentrations in the Northern Hemisphere explained by boreal forest fires in North America and Russia, Geophys. Res. Lett., 28, 4575-4578, 2001.
Wotawa, G. and Trainer, M.: The influence of Canadian forest fires on pollutant concentrations in the United States, Science, 288, 324, doi:10.1126/science.288.5464.324, 2000.

Yurganov, L. N., Duchatelet, P., Dzhola, A. V., Edwards, D. P., Hase, F., Kramer, I., Mahieu, E., Mellqvist, J., Notholt, J., Novelli, P. C., Rockmann, A., Scheel, H. E., Schneider, M., Schulz, A., Strandberg, A., Sussmann, R., Tanimoto, H., Velazco, V., Drummond, J. R., and Gille, J. C.: Increased Northern Hemispheric carbon monoxide burden in the troposphere in 2002 and 2003 detected from the ground and from space, Atmos. Chem. Phys., 5, 563-573, doi:10.5194/acp-5-563-2005, 2005.

Zhang, L., Jacob, D. J., Boersma, K. F., Jaffe, D. A., Olson, J. R., Bowman, K. W., Worden, J. R., Thompson, A. M., Avery, M. A., Cohen, R. C., Dibb, J. E., Flock, F. M., Fuelberg, H. E., Huey, L. G., McMillan, W. W., Singh, H. B., and Weinheimer, A. J.: Transpacific transport of ozone pollution and the effect of recent Asian emission increases on air quality in North America: an integrated analysis using satellite, aircraft, ozonesonde, and surface observations, Atmos. Chem. Phys., 8, 6117-6136, doi:10.5194/acp-8-6117-2008, 2008. 